\title{
Dynamics of phytoplankton productivity and exopolysaccharides (EPS and TEP) pools in the Seine Estuary (France, Normandy) over tidal cycles and over two contrasting seasons
}

\author{
Morelle Jérôme ${ }^{1,2}$, Schapira Mathilde ${ }^{3}$, Claquin Pascal ${ }^{1,2, *}$
}

\author{
${ }^{1}$ Normandie Université, Université de Caen-Normandie, Esplanade de la paix, F-14032 Caen, France \\ 2 UMR BOREA (CNRS-7208, IRD-207, MNHN, UPMC, UCBN), Esplanade de la paix, F-14032 Caen, \\ France \\ ${ }^{3}$ Ifremer, LER/N, Avenue du Général de Gaulle, 14520 Port-en-Bessin, France \\ * Corresponding author : Pascal Claquin, email address : pascal.claquin@unicaen.fr
}

\begin{abstract}
:
Exopolysaccharides (EPS) play an important role in the carbon flux and may be directly linked to phytoplankton and microphytobenthos production, most notably in estuarine systems. However the temporal and spatial dynamics of estuarine EPS are still not well understood, nor how primary productivity triggers this variability at these different scales.
\end{abstract}

The aim of this study was to investigate the primary productivity of phytoplankton and EPS dynamics in the Seine estuary over a tidal cycle in three different haline zones over two contrasted seasons. The other objectives was to investigate the origin of pools of soluble carbohydrates (S-EPS) and transparent exopolymeric particles (TEP) in phytoplankton, microphytobenthos or other compartments. High frequency measurements of productivity were made in winter and summer 2015. Physical and chemical parameters, biomass and EPS were measured at hourly intervals in sub-surface waters and just above the water sediment-interface.

Our results confirmed that high frequency measurements improve the accuracy of primary productivity estimations and associated carbon fluxes in estuaries. The photosynthetic parameters were shown to be strongly controlled by salinity and by the concentrations of suspended particle matter at the smallest temporal and at spatial scales. At these scales, our results showed an inverse relationship between EPS concentrations and biomass and productivity, and a positive relationship with sediment resuspension. Additionally, the distribution of EPS appears to be linked to hydrodynamics with the tide at daily scale and with the winter at seasonal scale. At spatial scale, the maximum turbidity zone played an important role in the distribution of TEP.

Our results suggest that, in the Seine estuary, between $9 \%$ and $33 \%$ of the S-EPS pool in the water column can be attributed to phytoplankton excretion, while only $0.4 \%-1.6 \%$ (up to $6.14 \%$ in exceptional conditions) originates from the microphytobenthos compartments. Most EPS was attributed to 
remobilization of detrital carbon pools in the maximum turbidity zone and in the sediment or allochthonous origin.

\section{Highlights}

- Accurate estimation of primary productivity in estuaries requires frequent measurements. An inverse relationship found between EPS concentrations and biomass and productivity. Only a minor fraction of the EPS pool was directly attributed to primary production. TEP concentration was strongly controlled by hydrodynamics.

Keywords : Phytoplankton, Microphytobenthos, PAM fluorometer, Electron transport rate 


\section{Introduction}

Located at the interface between the land and marine environments, estuaries provide economic,

cultural and ecological benefits to communities (Viles and Spencer 1995; Higgins et al. 2010; Barbier and Hacker 2011). Estuaries are strategic areas for human activities but are also vital for wildlife, as they provide a wide variety of habitats for nesting and feeding (Ayadi et al. 2004; Kaiser 2011). Longterm management of estuarine ecosystems is currently seriously threatened by anthropogenic pressure and climate change (Porter et al. 2013), and requires a better understanding of the structure and function of the organisms at the base of the food web. The estuarine food web is based on organic matter, which can be of autochthonous or allochthonous origin. Primary production by microalgae (i.e. phytoplankton and microphytobenthos) accounts for a large proportion of autochthonous production in many estuaries (Underwood and Kromkamp 1999; Cloern et al. 2014). Primary production in estuaries varies considerably in space and over time, making it difficult to scale up measurements (Shaffer and Onuf 1985). Indeed, estuaries are unique aquatic environments that receive inputs derived from freshwater outflows from rivers and mechanical energy from tides (Cloern 1991; Statham 2012). In addition to processes in open oceans that explain their variability, in estuaries, primary producer dynamics is the result of many processes on land, in the atmosphere, in the ocean and in the underlying sediments (Cloern 1996; Morse et al. 2014). Many of these processes fluctuate over a wide range of timescales and the geographical position of each estuary characterizes the relative strength of these processes operating at annual, seasonal, monthly, daily and even at event timescales (Cloern and Jassby 2010; Parizzi et al. 2016).

Apart from photosynthesis of organic matter, a significant proportion of primary production is released as extracellular polysaccharides (EPS) (Passow 2002). EPS are mainly made up of a free fraction of soluble carbohydrates (S-EPS) (Underwood et al. 1995) composed of galactose and glucuronic acid (De Brouwer et al. 2002), but also of a particle fraction in the form of transparent exopolymer particles (TEP), mainly composed of fucose and rhamnose (Fukao et al. 2009). These exopolymers play an important role in aggregation processes, particle sedimentation and carbon fluxes in aquatic ecosystems (e.g. Passow et al. 2001; Bhaskar \& Bhosle 2005). Moreover, the production of EPS allows the creation of microenvironments in which cells are protected from rapidly changing 
environmental conditions, toxins, grazing, and even digestion (Decho 2000). In estuarine systems, EPS

have been shown to account for a large proportion of the colloidal organic carbon pool in the water column (Annane et al. 2015) and high concentrations of TEP have been found in the maximum turbidity zone (MTZ) of estuaries where suspended particle matter (SPM) accumulates (Malpezzi et al. 2013). However, most research on EPS in estuaries has focused on their production by microphytobenthic communities and only a few authors have studied EPS and TEP dynamics in the estuarine water column (Wetz et al. 2009; Annane et al. 2015). As a result, the link between phytoplankton primary production and the concentration of exopolymers in estuaries remains to be explored.

In estuaries, in addition to temperature and light, factors that potentially control primary production are forced by tide variability and also by river runoff and nutrient inputs (Sun et al. 2012). At a small scale, tidal regimes play a fundamental role in phytoplankton dynamics, as the movement of water masses causes notable variations in salinity, and in SPM and nutrient concentrations (Monbet 1992; Jouenne et al. 2007; Gameiro and Brotas 2010). Moreover, a strong salinity gradient in the estuary can profoundly influence the distribution, dynamics and production of phytoplankton, which include riverine, coastal and estuarine taxa (Muylaert et al. 2009). At seasonal scales, in temperate estuaries, phytoplankton dynamics are characterized by higher freshwater species biomass during the high flow period (i.e. winter) and high neritic diatom biomass during the low flow period (i.e. summer) (Cloern et al. 1985; Alpine and Cloern 1992). In sum, phytoplankton productivity can vary considerably over a wide range of scales, which, in turn, can strongly affect the biogeochemical functioning of the estuary. Despite the need to better understand the dynamics of phytoplankton and primary production at these different scales, only a few studies have addressed the variability of phytoplankton primary production over a tidal cycle (Cloern 1991; Desmit et al. 2005). In this context, it is vital to investigate the factors that control photosynthetic processes and carbon excretion by phytoplankton in estuaries.

Assessing small-scale temporal variability, such as the variability expected over a tidal cycle, requires high frequency measurements. The Pulse Amplitude Modulated (PAM) fluorometry method, based on the measurement of variation in fluorescence of the photosystem II (PSII), provides high frequency measurements of photosynthetic parameters (Kromkamp and Forster 2003). While this method does not 
directly measure the incorporation of photosynthetic carbon (Kolber and Falkowski 1993; Barranguet

and Kromkamp 2000), it enables monitoring of the dynamics of photosynthetic parameters directly linked to carbon incorporation (Claquin et al. 2004; Napoleon et al. 2012).

The present study was conducted along the macro-tidal part of the Seine estuary, which forms the biggest outflow into the English Channel. Given the variability of physical forcing in estuaries, the aim of this work was to investigate the dynamics of EPS (S-EPS and TEP) in the water column and phytoplankton primary productivity at appropriate temporal scales. Our specific objectives were to (1) study the relationships between short-term EPS dynamics and phytoplankton primary productivity over tidal cycles, (2) assess their variability along the salinity gradient, (3) explore these relationships over two contrasted seasons: high flow/winter (February) and low flow/summer (July) and, finally (4) to estimate the potential relative contribution of autochthonous phytoplankton primary production and microphytobenthic productive mudflats, to the EPS pool in a temperate estuary.

\section{Methods}

\subsection{Study site}

The Seine River and its estuary drain an area of $76,260 \mathrm{~km}^{2}$. After Paris, the river flows northwest and drains into the English Channel. Located $202 \mathrm{~km}$ from Paris (the kilometric scale of the Seine River is set at $0 \mathrm{~km}$ in the center of Paris), the weir at Poses represents the upper limit of tidal propagation of the Seine estuary (Fig. 1). The annual mean discharge of the river measured at Poses is $436 \mathrm{~m}^{3} / \mathrm{s}$. During the sampling year, the high flow period extending from January to May with a mean discharge of 750 $\mathrm{m}^{3} / \mathrm{s}$ and values reaching $1,240 \mathrm{~m}^{3} / \mathrm{s}$ and a mean discharge of $245 \mathrm{~m}^{3} / \mathrm{s}$ during low flow period (Data GIP Seine-Aval, 2008; 2011). Salinity ranges between (i) 0.5 and 5 in the oligohaline part, (ii) 5 and 18 in the mesohaline part, (iii) 18 and 30 in the polyhaline part, and (iv) salinity is higher than 30 in the euhaline part of the Seine estuary. The Seine estuary is a macrotidal estuary, whose tidal amplitude ranges from 3 to $7 \mathrm{~m}$ at Honfleur and from 1 to $2 \mathrm{~m}$ at Poses. The mean residence time in the estuary ranges from 17 to 18 days for a discharge of $200 \mathrm{~m}^{3} / \mathrm{s}$ at Poses and from 5 to 7 days for a discharge of 1,000 $\mathrm{m}^{3} / \mathrm{s}$ (Brenon and Hir 1999; Even et al. 2007). The tide in the Seine estuary is characterized by 
flattening at high tide that lasts for more than 2 hours due to the deformation of the tidal wave during propagation at shallow depths (Brenon and Hir 1999; Wang et al. 2002). The flow is asymmetric in favor of the flood and this trend increases when the tide propagates up the estuary (Le Hir et al. 2001). Water temperatures range from $25{ }^{\circ} \mathrm{C}$ in summer to $7{ }^{\circ} \mathrm{C}$ in winter with differences of less than $1{ }^{\circ} \mathrm{C}$ along the longitudinal axis and a weak vertical gradient (Data GIP Seine-Aval, 2008; 2011). The estuary is characterized by the formation of a maximum turbidity zone (MTZ) containing up to $2 \mathrm{~g} / \mathrm{L}$ of SPM, usually located between Honfleur and Tancarville. However, depending on the intensity of the tide and river discharge, the MTZ may move upstream, and, during winter flood events, the MTZ may be flushed out into the Seine Bay (Etcheber et al. 2007; Garnier et al. 2010).

\subsection{Sampling strategy}

\section{Water column sampling}

Sampling was conducted in February (winter - high flow period) and July (summer - low flow period) 2015 onboard the vessel "Côtes de la Manche". During both periods, sampling was conducted under similar tidal conditions (i.e. the tidal range and the highest tidal elevation during daylight were similar), at three sites distributed along the salinity gradient (Fig. 1): in the euhaline part at the river plume (La Carosse - sampled on February 3 and July 18), in the mesohaline zone (Fatouville - sampled on February 4 and July 20) and in the oligohaline zone (Tancarville - sampled on February 5 and July 17). Sampling was conducted during daylight over a tidal cycle (i.e. 12 hours) at each of the three sites and during both campaigns. Photosynthetic parameters were measured in the surface water at fiveminute intervals (i.e. 12 measurements/hour). Vertical salinity (Practical Salinity Scale), turbidity (Nephelometric Turbidity Unit) and temperature $\left({ }^{\circ} \mathrm{C}\right)$ profiles were performed hourly with a SBE 19plusVD CTD (Seabird) from the sub-surface to $1 \mathrm{~m}$ above the water-sediment interface (WSI). Water was sampled from the sub-surface (i.e. $1 \mathrm{~m}$ ) and $1 \mathrm{~m}$ above the WSI using a 5 L-Niskin bottle at hourly intervals to measure hydrological (i.e. nutrients, suspended particular matter) and biological (i.e. chlorophyll $a$, EPS concentrations) parameters. 
Two other campaigns were conducted in September, 2014 and in April, 2015 at 15 sites distributed throughout the Seine estuary mudflats (the labels and coordinates are provided in the results section -

Tab. 2) to access the microphytobenthos dynamics (Morelle et al, in prep). Each site was sampled during the emersion period (more than one hour after the beginning of the exposure period and more than one hour before the return flow) and three replicated squares $(1 \mathrm{x} 1 \mathrm{~m})$ were chosen randomly at each site. In each square, three cores $(20 \mathrm{~cm}$ diameter $\times 1 \mathrm{~cm}$ deep) were taken. After being carefully homogenized, the volume of substratum was determined by using cut syringes, split into flasks for analyses. The concentrations of the EPS in the samples were measured.

\subsection{High-frequency measurements}

\subsubsection{Photosynthetic parameters}

In order to acquire high-frequency estimations of primary productivity, the maximum energy conversion efficiency (or the quantum efficiency of photosystem II (PSII) charge separation, $\mathrm{F}_{\mathrm{V}} / \mathrm{F}_{\mathrm{M}}$ ) was measured at 5-minute intervals using the flow through version of the WATER PAM (Waltz, Effeltrich, Germany) (Schreiber et al. 1986). Water collected from the sub-surface was conducted through a pipe to a thermally insulated dark reserve that maintained the sample close to the in situ temperature. After 5 min of dark acclimation, which was sufficient for the oxidation of the Quinone A $\left(\mathrm{Q}_{\mathrm{A}}\right)$ pool in this highly turbid environment, a sub-sample was automatically transferred into the measuring chamber. The sample was excited by a weak blue light $\left(1 \mu \mathrm{mol}\right.$ photon. $\mathrm{m}^{-2} \cdot \mathrm{s}^{-1}, 470 \mathrm{~nm}$, frequency $0.6 \mathrm{kHz})$ to record the minimum fluorescence $\left(F_{0}\right)$. The maximum fluorescence $\left(F_{M}\right)$ was obtained during a saturating light pulse $\left(0.6 \mathrm{~s}\right.$, up to $4000 \mu \mathrm{mol}$ photon. $\left.\mathrm{m}^{-2} \cdot \mathrm{s}^{-1}, 470 \mathrm{~nm}\right)$, allowing all the $\mathrm{Q}_{\mathrm{A}}$ pool to be reduced. $\mathrm{Fv} / \mathrm{F}_{\mathrm{M}}$ was calculated according to the following equation (Genty et al. 1989):

$\frac{F_{V}}{F_{M}}=\frac{\left(F_{M}-F_{0}\right)}{F_{M}}$

Samples were exposed to nine consecutive irradiances $(E)$ ranging from 0 to $469 \mu \mathrm{mol}$ photon. $\mathrm{m}^{-2} . \mathrm{s}^{-1}$ in winter and from 0 to 1541 in summer, for a period of $30 \mathrm{~s}$ for each light step. These different light 
and maximum fluorescence $\left(F_{M}{ }^{\prime}\right)$ were measured. The effective quantum efficiency of PSII for each irradiance was determined as follows (Genty et al. 1989) :

$191 \quad \frac{\Delta \mathrm{F}}{\mathrm{F}_{\mathrm{M}}{ }^{\prime}}=\frac{\left(\mathrm{F}_{\mathrm{M}}{ }^{\prime}-\mathrm{F}_{\mathrm{S}}\right)}{\mathrm{F}_{\mathrm{M}}{ }^{\prime}}$

192 The relative electron transport rate $\left(\mathrm{rETR}, \mu \mathrm{mol}\right.$ electron $/ \mathrm{m}^{2} / \mathrm{s}$ ) was calculated for each irradiance. $\mathrm{rETR}$ is a measure of the rate of linear electron transport through PSII, which is correlated with the overall 194 photosynthetic performance of the phytoplankton (Juneau and Harrison 2005):

$\operatorname{rETR}(\mathrm{E})=\frac{\Delta \mathrm{F}}{\mathrm{F}_{\mathrm{M}}{ }^{\prime}} \times \mathrm{E}$

Samples were removed from the Niskin bottle in sub-surface water and close to the WSI at hourly intervals. A sub-sample was placed in the measuring chamber of the cuvette version of the WATER PAM (Waltz, Effeltrich, Germany) and $\mathrm{F}_{\mathrm{V}} / \mathrm{F}_{\mathrm{M}}$ was measured as described above.

\subsubsection{P versus $\mathbf{E}$ curves}

To estimate the photosynthetic parameters, the rETR values were plotted against $E$ and the mechanistic model developed by Eilers \& Peeters (1988) was applied to fit the data using SigmaPlot (Systat

Software) according to the equation (4) with $a, b$ and $c$ initially set to $3 \times 10^{-5} ; 0.06$ and 111 respectively:

$\operatorname{rETR}(\mathrm{E})=\frac{\mathrm{E}}{\left(\mathrm{a} \mathrm{E}^{2}+\mathrm{bE}+\mathrm{c}\right)}$

After 200 iterations of fit per curve, the best $a, b$ and $c$ parameters were estimated by the software for each $\mathrm{rETR} / \mathrm{E}$ curve and the maximum photosynthetic capacity $\mathrm{rETR}_{\max }$ was calculated as follows:

$\mathrm{rETR}_{\max }=\frac{1}{(\mathrm{~b}+2 \sqrt{\mathrm{ac}})}$

\subsection{Discrete measurements}

\subsubsection{Nutrients}

211 To determine nutrient concentrations $\left(\mathrm{PO}_{4}{ }^{3-}, \mathrm{NO}_{3}{ }^{-}, \mathrm{NO}_{2}{ }^{-}, \mathrm{NH}_{4}{ }^{+}\right.$and $\left.\mathrm{Si}(\mathrm{OH})_{4}\right), 100 \mathrm{ml}$ water samples 212 were pre-filtered through a $48 \mu \mathrm{m}$ Nylon Mesh (Sefar Nitex 03-48/31-102 cm; Open area \%: 30) 

Kérouel 2004, 2007). For the measurement of silicate concentrations $\left(\mathrm{Si}(\mathrm{OH})_{4}\right)$, water samples were subsequently filtered through $0.45 \mu \mathrm{m}$ acetate cellulose membrane and stored at $4{ }^{\circ} \mathrm{C}$ until analysis. For the measurement of dissolved inorganic nitrogen (i.e. $\mathrm{DIN}=\mathrm{NO}_{3}^{-}+\mathrm{NO}_{2}^{-}+\mathrm{NH}_{4}^{+}$) and phosphate concentrations $\left(\mathrm{PO}_{4}^{3-}\right)$, water samples were stored directly at $-20{ }^{\circ} \mathrm{C}$. Samples were analyzed within one month after field collection with an auto-analyzer (Technicon III) following standard protocols (Aminot and Kérouel 2007; Hydes et al. 2010). The limits of quantification were $0.2 \mu \mathrm{M}$ for silicates, $0.1 \mu \mathrm{M}$ for nitrates, $0.02 \mu \mathrm{M}$ for nitrites, $0.04 \mu \mathrm{M}$ for phosphates and $0.1 \mu \mathrm{M}$ for ammonia.

\subsubsection{Suspended particulate matter}

Surface and bottom water samples were collected from the Niskin bottle at hourly intervals over the

$12 \mathrm{~h}$ tidal cycle. Before the field campaign, Whatman GF/F glass microfiber $0.7 \mu \mathrm{m}$ filters were

prepared and rinsed using the vacuum filtration system, dried at $50{ }^{\circ} \mathrm{C}$ for $24 \mathrm{~h}$, and pre-weighed. A known volume of the sampled water was filtered through the prepared filters using a glass tank on a filter ramp connected to a pump. Filters were rinsed with distilled water to remove any remaining salt. ensured a precision of $0.0001 \mathrm{~g} / \mathrm{L}$ for the lowest SPM concentrations (Verney et al. 2009).

\subsubsection{Phytoplankton biomass}

Phytoplankton biomass was assessed through chlorophyll $a$ (chla) concentrations. Samples (30 to 500 $\mathrm{ml}$ ) were filtered in triplicate, through glass fiber filters (Whatman GF/F: $0.7 \mu \mathrm{m}$ pore size and $47 \mathrm{~mm}$ diameter) and immediately frozen at $-20{ }^{\circ} \mathrm{C}$ until analysis. In the laboratory, pigments were extracted in $10 \mathrm{~mL}$ of $90 \%(\mathrm{v} / \mathrm{v})$ acetone, for $12 \mathrm{~h}$ at $4{ }^{\circ} \mathrm{C}$ in the dark. After centrifugation $\left(3000 \mathrm{~g}, 4{ }^{\circ} \mathrm{C}, 10\right.$ minutes), the chla concentration $(\mu \mathrm{g} / \mathrm{L})$ was measured on extracts according to the fluorometric method of Lorenzen (1966) and using a Turner Trilogy fluorometer (Turner Designs, Sunnyvale, California, USA). 


\subsubsection{Extracellular polymeric substances}

\section{Water column pools}

243 The concentration of TEP was determined using the colorimetric method described by Claquin et al. (2008) adapted from Passow and Alldredge (1995). Briefly, 15 to $50 \mathrm{ml}$ samples were filtered onto 0.4 $\mu \mathrm{m}$ polycarbonate Isopore membrane filters (Millipore) and stored at $-20{ }^{\circ} \mathrm{C}$ until analysis. Particles retained on the filters were stained with $5 \mathrm{ml}$ of $0.02 \%$ Alcian blue (Sigma) in $0.06 \%$ acetic acid (pH 2.5). After centrifugation at $3500 \mathrm{~g}$ for $30 \mathrm{~min}$, the supernatants were removed and the filters were centrifuged several times with $5 \mathrm{ml}$ of MilliQ water until all excess dye was completely removed from the pellet. After one night of drying in a sterilizer at $50{ }^{\circ} \mathrm{C}, 6 \mathrm{ml}$ of $80 \% \mathrm{H}_{2} \mathrm{SO}_{4}$ were added and 2 hours later the absorption of the supernatant was measured using a spectrometer at $787 \mathrm{~nm}$. Alcian blue absorption was calibrated using a solution of Xanthan gum $(\mathrm{XG})$ as a standard. TEP concentrations are expressed in $\mu \mathrm{gXGeq} / \mathrm{L}$. Subsequently, to estimate the TEP pool in the water column, the TEP concentrations were converted into carbon $(\mathrm{mgC} / \mathrm{L}$ ) using a coefficient of 0.70 (Engel and Passow 2001; Claquin et al. 2008). calibration curve. S-EPS concentrations are expressed in $\mu \mathrm{gGeq} / \mathrm{L}$. 
contamination of EPS extracts by chrysolaminarin stored in the vacuoles (Chiovitti et al. 2004;

Takahashi et al. 2009). Following Orvain et al. (2014), microphytobenthic EPS was extracted from 5 ml

of fresh sediment placed in $15 \mathrm{ml}$ centrifugation tubes with $5 \mathrm{ml}$ of $0.2 \mu \mathrm{m}$ filtered and sterilized artificial sea water. After one hour of incubation in artificial seawater, tubes were mixed and centrifuged at $4{ }^{\circ} \mathrm{C}, 3000 \mathrm{~g}$ for $10 \mathrm{~min}$. Supernatants containing the colloidal fraction were collected in a new centrifugation tube and stored frozen $\left(-20{ }^{\circ} \mathrm{C}\right)$ until analysis. The method described above for phytoplanktonic S-EPS was used. Each EPS concentration was first expressed as a function of the volume of fresh sediment (mgGeq/L) and was then converted into contents (mgGeq/gDW) by using the using the Lorenzen method (1966), were used to express the S-EPS:chl $a$ ratio in $\mathrm{mgGeq} / \mathrm{mgchl} a$.

\section{Results}

\subsection{Spatial and temporal dynamics of the water column along the salinity gradient}

The temperature, salinity and nutrient dynamics are characteristic of North European estuaries (Fig. $\mathrm{S} 1 \& \mathrm{~S} 2)$. The main points regarding these parameters are the higher temperature $\left(>18{ }^{\circ} \mathrm{C}\right)$ and the lower river flow in summer $\left(<226 \mathrm{~m}^{3} / \mathrm{s}\right)$ versus winter (temperature $<7^{\circ} \mathrm{C}$ and flow $\left.>1110 \mathrm{~m}^{3} / \mathrm{s}\right)$. In 
294 in summer and up to Fatouville in winter. In summer, despite the low river flow, nutrient concentrations remained high (between 9.17 and $413.54 \mu \mathrm{M}$ for [DIN], between 5.22 and $160.20 \mu \mathrm{M}$ for [Si] and, between 0.36 and $4.17 \mu \mathrm{M}$ for [P]) and were not limiting for phytoplankton growth during this period. [DIN] and [Si], were closely linked to freshwater inputs and decreased from upstream to downstream.

In contrast, $[\mathrm{P}]$ was positively correlated with the tidal height and the highest concentrations were recorded in the mesohaline part of the estuary.

The highest SPM concentrations were recorded close to the WSI, at Fatouville during winter, and at

Tancarville during summer (Tab. 1). The sampling site La Carosse displayed characteristics of marine

waters with very low SPM concentrations. At Fatouville in winter, peaks of SPM were recorded close to the WSI at the beginning of the high tide and during the ebb (fig. S3), whereas very low SPM concentrations were observed during the high tide slack. A very similar pattern was observed in summer, with high SPM concentrations recorded close to the WSI at the beginning of the high tide and at low tide. At Tancarville, a peak was recorded at both depths during the ebb in winter, and during low

tide in summer. These observations suggest that SPM concentrations were closely linked to resuspension of bottom sediments triggered by tidal currents rather than to inputs from the watershed.

\subsection{Discrete measurements of chla biomass and photosynthetic parameters}

The chla concentrations were low in winter (Tab. 1) with minor variations at La Carosse and Tancarville (Fig. 2). Only three peaks were recorded close to the WSI at Fatouville associated with SPM dynamics (during the flood, the high tide slack and the ebb). In summer, at La Carosse, an increase was recorded during the flood at both depths but the increase was bigger at the surface. At Fatouville, chla concentrations were low close to the WSI except for a peak at low tide slack. In surface 
waters, values were low at low tide slack but increased considerably from the flood to the high tide

slack. At Tancarville, the chla concentrations decreased during the flow and increased during the ebb at both depths.

At La Carosse, despite low chl $a$ in winter, $\mathrm{F}_{\mathrm{V}} / \mathrm{F}_{\mathrm{M}}$ values were high (Tab. 1). The highest $\mathrm{F}_{\mathrm{V}} / \mathrm{F}_{\mathrm{M}}$ values were recorded at both depths during tide slack. However, marked variations were recorded over the tidal cycle (Fig. 2), two reductions were recorded during the flood and during the ebb at both depths. At Fatouville, $\mathrm{F}_{\mathrm{V}} / \mathrm{F}_{\mathrm{M}}$ values were low and remained constant throughout the day. At Tancarville, two reductions were recorded, one during the flow and the other at the beginning of the ebb. Despite the high chla concentrations in summer, $\mathrm{F}_{\mathrm{V}} / \mathrm{F}_{\mathrm{M}}$ were lower than in winter. At La Carosse, at both depths, $\mathrm{F}_{\mathrm{V}} / \mathrm{F}_{\mathrm{M}}$ increased during the flood, decreased during high tide and increased during the ebb. At Fatouville, $\mathrm{F}_{\mathrm{V}} / \mathrm{F}_{\mathrm{M}}$ were closely linked to the dynamics of the tide characterized by a decreasing trend during the ebb followed by an increase with the flow to reach maximum values during high tide. At Tancarville, $\mathrm{F}_{\mathrm{V}} / \mathrm{F}_{\mathrm{M}}$ values were very low with high variability over the tidal cycle.

\subsection{High frequency measurements of photosynthetic parameters}

Primary productivity estimated using high frequency $\mathrm{rETR}_{\max }\left(\mu \mathrm{mol}\right.$ electron $/ \mathrm{m}^{2} / \mathrm{s}$ ) measurements showed a high degree of variability at very small temporal scale $(5 \mathrm{~min})$ compared with hourly observations (Fig. 3). In winter, productivity values were low (Tab. 1). At La Carosse, rETR max decreased during the flow, increased during high tide and decreased at the beginning of the ebb followed by marked variability of the values. At Fatouville, rETR $_{\max }$ increased during the flow, when currents were at their maximum, and decreased during tide slacks. At Tancarville, despite the high degree of variability, the $\mathrm{rETR}_{\max }$ remained close to a mean value of $30.16 \pm 6.42 \mu \mathrm{mol}$ electron $/ \mathrm{m}^{2} / \mathrm{s}$. In summer, $\mathrm{rETR}_{\max }$ values were higher than in winter throughout the salinity gradient (Tab. 1). At La Carosse, the dynamics of phytoplankton productivity increased from low tide to half the flow. Thereafter a decrease was observed during the high tide before a slight increase at the beginning of the ebb. At Fatouville, productivity mirrored tidal dynamics but with a time lag of approximately three 
hours. At Tancarville, an increase in productivity from the morning low tide to high tide was followed

by a decrease from high tide to the evening low tide.

\subsection{Extracellular polymeric substances.}

\subsubsection{Transparent exopolymeric particles (TEP)}

At each site, TEP concentrations ([TEP], mgXGeq/L) were higher close to the WSI than in subsurface waters (Tab. 1) and [TEP] peaks were mostly recorded during flows (Fig. 4). In winter, at La Carosse, three peaks were recorded close to the WSI: two during the high tide, mirroring the tide dynamics, and one at the end of the ebb. In sub-surface waters, a peak was recorded at the beginning of the flow and an increasing trend was recorded during the ebb. At Fatouville, high variability was observed close to the WSI with values increasing both during the flow and the ebb. At the surface, the same dynamics were observed but with lower values. At Tancarville, some [TEP] peaks were also observed during the flow and the ebb at both depths. During summer, [TEP] variations at La Carosse were weak despite two small peaks close to the WSI recorded during the flow. Upstream, at Fatouville and Tancarville, high peaks were recorded during low tide at both depths, small peaks were also recorded at high tide at both these sites. Thus, during the campaigns, it appears that between 0.36 and $48.08 \mathrm{mgC} / \mathrm{L}$ and a mean of $5.89 \mathrm{mgC} / \mathrm{L}$ were available for the trophic network in the form of TEP.

The TEP:chl $a$ ratios were higher in winter than in summer (Tab. 1). Some decreasing trends in the TEP:chl $a$ ratio were recorded at high tide slacks in the sub-surface water at La Carosse in both seasons and in summer at Fatouville at both depths with an inverse dynamics with respect to the tide (Fig. S4). Some negative peaks were also recorded at the end of the high tide slacks.

\subsubsection{Soluble carbohydrates (S-EPS)}

\section{Water column pools}

Despite high variability, the S-EPS concentrations ([S-EPS]) were higher close to the WSI than in sub-surface waters and in winter than in summer (Tab. 1). Some peaks were recorded at both depths mainly during the reverse flows (before and after the tide slacks) (Fig. 5). The highest peaks and the 
highest variability were observed close to the WSI. In winter, high variability was recorded at Fatouville

during the ebb. In summer, at La Carosse, highly variable values were recorded during low tide especially in sub-surface waters whereas inverse patterns were observed at the two sampling depths. At Fatouville, [S-EPS], the same patterns were observed at both depths with decreasing values at slack tides and peaks during the flows. At Tancarville, [S-EPS] were characterized by a marked increase close to the WSI at high tide and high variability during the ebb.

EPS:chl $a$ ratios presented some peaks at both depths (Fig. S5). In winter at La Carosse, a strong peak was observed close to the WSI at the end of the ebb. In summer, the highest values were recorded close to the WSI during the ebb. In winter at Fatouville, EPS:chla ratios in sub-surface waters increased during the high tide and were variable at the beginning of the ebb, while close to the WSI, some peaks were recorded during the tide slacks and the ebb. In summer, a strong peak was recorded in sub-surface waters during the flow, followed by a marked decrease during the high tide slack. Close to the WSI, a peak was recorded at the end of the ebb. In winter at Tancarville, an increase in the EPS:chla ratio was recorded at the end of the ebb close to the WSI. In summer, values were low at both depths during the low tide and the flow. Two peaks were recorded close to the WSI during the high tide slack and the ebb and one peak was recorded in sub-surface waters at high tide.

\section{Intertidal sediment pools}

S-EPS concentrations on the Seine estuary mudflats also displayed high variability among the 15 sites sampled (Tab. 2; Morelle et al, in prep). Values ranged between 61.02 and $526.04 \mathrm{mgGeq} / \mathrm{m}^{2}$ also varied between seasons with a higher mean value in September $\left(310.81 \pm 129.61 \mathrm{mgGeq} / \mathrm{m}^{2}\right)$ than in April $\left(157.06 \pm 66.16 \mathrm{mgGeq} / \mathrm{m}^{2}\right)$. In contrast, the EPS:chla ratios were often higher in April $(19.74 \pm$ $24.08 \mathrm{mgGeq} / \mathrm{mgchl} a)$ than in September $(9.50 \pm 8.93 \mathrm{mgGeq} / \mathrm{mgchl} a)$.

\subsection{Relationships between biological parameters and environmental variables}

Principal component analyses (PCA) were performed on the data set to explore the relationships between biological and abiotic parameters (Fig. 6). The $1^{\text {st }}$ and $2^{\text {nd }}$ components explained $65.26 \%$ of the 
total inertia while the $1^{\text {st }}$ and the $3^{\text {rd }}$ dimensions explained $59.40 \%$ of total inertia (Tab. 3 ). The first

principal components ( $\mathrm{PC} 1 ; 41 \%$ of variance) formed a typical estuarine axis with parameters related to the inflow of marine waters such as salinity $(32 \%)$ on the left hand side of axis 1 , and parameters related to freshwater inputs, such as $\mathrm{Si}(23 \%)$ and DIN (33\%) concentrations on the right hand side of axis 1. The second principal component (PC2; 24\%) was strongly influenced by factors related to seasonal changes such as PAR (38\%) and temperature (48\%). The third principal components (PC3; 18\%) was related to P concentrations (58) and SPM (21\%). The chla concentrations (chl $a$ ) were positively correlated with temperature (Spearman correlation coefficient (SCC): 0.59; $p<0.001 ; n=150$ ) and PAR (SCC: $0.42 ; \mathrm{p}<0.001 ; \mathrm{n}=150$ ). In the same way, productivity was positively correlated with temperature (SCC: 0.60; $\mathrm{p}<0.001 ; \mathrm{n}=75$ ) and PAR (SCC: 0.66; $\mathrm{p}<0.001 ; \mathrm{n}=75$ ). Indeed, the high temperatures and high solar irradiance in summer provide the best environmental growth conditions for phytoplankton. The chl $a$ was negatively correlated with P concentration (SCC: $-0.20 ; \mathrm{p}<0.05 ; \mathrm{n}=150$ ) as confirmed by their position in the $1^{\text {st }} / 3^{\text {rd }}$ dimensions of the PCA (Fig. 9). $F_{V} / F_{M}$ was positively correlated with salinity (SCC: $0.22 ; \mathrm{p}<0.01 ; \mathrm{n}=150$ ), and negatively correlated with temperature (SCC: $-0.27 ; \mathrm{p}<0.01 ; \mathrm{n}=150$ ), and SPM (SCC: $-0.15 ; \mathrm{p}=0.06 ; \mathrm{n}=150$ ) concentrations. [TEP] were positively correlated with SPM (SCC: $0.17 ; \mathrm{p}<0.05 ; \mathrm{n}=150)$. The [S-EPS], S-EPS:chl $a$ and TEP:chl $a$ ratios were negatively correlated with temperature, PAR, chl $a$ and productivity (SCCs: $<-0.44 ; \mathrm{p}<0.001 ; \mathrm{n}=150$ ).

\section{Discussion}

\subsection{Dynamics of biological parameters in the Seine estuary in relation with environmental} parameters

Our study revealed high variability of photosynthetic parameters in the estuary, where small-scale variability (i.e. 5 minutes) can be greater than variability at tidal scale (Fig. 3). Less frequent measurements could thus easily result in over- or underestimation of these parameters, thereby highlighting the complexity of estimating primary productivity in these dynamic ecosystems. Moreover, variability appeared to be higher and more frequent before or after the low or the high tide at which time 
turbulence and the concentrations of SPM generally reach maximum levels thereby preventing light

from penetrating and hence preventing photosynthesis.

Even though variations in nutrient concentrations are known to play a major role in phytoplankton dynamics in many ecosystems, in many estuaries, it has been shown that nutrients do not control phytoplankton growth because they are largely in excess (Kromkamp et al. 1995; Cai et al. 2004). However, in this study, $\mathrm{P}$ concentrations were negatively correlated with phytoplankton biomass and productivity (Fig. 6). This could be the result of the consumption of $\mathrm{P}$ by phytoplankton but $\mathrm{P}$ concentrations within the estuary (> $0.62 \mu \mathrm{mol} / \mathrm{L}$ for all the samples) remained higher than those usually observed during the same period in the Seine Bay (i.e. $\leq 0.04 \mu \mathrm{M}$ ) where phytoplankton grow easily. Moreover, previous studies have shown that P does not limit phytoplankton growth in the Seine estuary (Némery and Garnier 2007; Passy et al. 2016). Phosphate has a strong affinity for sorption and desorption reactions with SPM, which create high fluxes and is an important source of dissolved P in the MTZ (Némery and Garnier 2007). Therefore, this negative relationship may rather be related to a positive relationship between $\mathrm{P}$ and SPM that reduces light penetration into the water column, and consequently results in low phytoplankton biomass and productivity. Thus, like in many temperate estuaries, phytoplankton productivity in the Seine estuary is mainly controlled by light availability.

The physiological status of the cells $\left(\mathrm{F}_{\mathrm{V}} / \mathrm{F}_{\mathrm{M}}\right)$ was low within the MTZ during both study periods (Tab. 1). This could be explained by the intense resuspension of dead cells and SPM in this area, which reduced light penetration, especially during the flow and ebb. Additionally, the physiological changes in the phytoplankton caused by the contrast between freshwater outflow and marine water inflow have been shown to cause physiological stress and cell lysis (Lionard et al. 2005; Servais and Garnier 2006; Hernando et al. 2015). However, despite weak $\mathrm{F}_{\mathrm{V}} / \mathrm{F}_{\mathrm{M}}$, phytoplankton productivity levels in the MTZ (Fatouville in winter and Tancarville in summer) were in the same order of magnitude as those measured at the two other sites in the same season (Tab. 1). This result shows that photosynthetic activity of living cells is possible in the MTZ despite the high level of stress. More surprisingly, $\mathrm{F}_{\mathrm{V}} / \mathrm{F}_{\mathrm{M}}$ values were higher close to the WSI than in sub-surface waters. These results suggest that, despite the high concentrations of SPM close to the WSI and the subsequent reduction in light penetration into the 
water column, phytoplankton cells were able to survive and even to maintain a high physiological

status. The deep water layer corresponds to marine water with a residence time ranging from 5 to 18 days (Brenon and Hir 1999; Even et al. 2007). This observation suggests that these photosynthetic cells are able to rapidly return to a high productive status as soon as they access light. This result further implies that organic matter in the bottom layer of the Seine Estuary is probably not only composed of detrital matter but also of living phytoplankton cells. This observation may have major implications for trophic transfer between pelagic and benthic organisms in this part of the estuary.

In winter, at spatial scale, phytoplankton biomass and productivity were higher in the oligohaline zone (Tancarville) than in the euhaline zone (La Carosse) (Tab. 1). The winter season involves an increase in freshwater discharge and can increase phytoplankton growth, as already observed in the Godavari estuary (Sarma et al. 2009) and in the Chesapeake estuary (Adolf et al. 2006). The higher productivity observed at Fatouville (MTZ) at low tide rather than at high tide (Fig. 3) suggests higher primary productivity in fresh waters than in saline waters during this period. Different community composition in these distinct water masses could explain this result. Indeed, in winter, high primary production in freshwater has been reported in other estuarine systems (Servais and Garnier 2006; Lehman 2007) where it was attributed to specific freshwater phytoplankton communities (Malpezzi et al. 2013). The presence of cyanobacteria in the outer part of estuary could also explain the low level of primary productivity measured in the oligohaline zone of the estuary in winter: cyanobacteria display lower productivity than eukaryotic phytoplankton (Masojidek et al. 2001; Macintyre et al. 2002). PAM measurements may have underestimated cyanobacteria productivity, as the blue light used in the present study is weakly absorbed by the prokaryotic fraction of the phytoplankton (Glover et al. 1985; Suggett et al. 2004). In addition, the $F_{V} / F_{M}$ is known to be poorly estimated in cyanobacteria because of the state transition processes (Campbell et al. 1998).

In summer, the low discharge enables upstream migration of marine and estuarine species (Josselyn and West 1985), which could explain the high phytoplankton biomass observed close to the WSI at Fatouville and Tancarville (Tab. 1). The high phytoplankton growth rate observed in the Seine river plume led to an increase in productivity at La Carosse at the beginning of the flow (Fig. 3). During the 
ebb, a decrease in productivity was observed, possibly the consequence of the increase in SPM and the

subsequent reduction in light penetration, or potential damage to phytoplankton cells caused by the mechanical stress associated with strong hydrodynamics, as previously shown in other estuarine systems (Cloern et al. 1985; Servais and Garnier 2006). The highest primary productivity in summer was observed at Fatouville in the mesohaline zone (Tab. 1). At this site, primary productivity increased with the flow and decreased with the ebb (Fig. 3). This result suggests that phytoplankton growth occurred in the polyhaline zone between La Carosse and Fatouville where the concentrations of nutrients were still high and light still available, but not in the other zones.

\subsection{Dynamics of EPS in the Seine estuary in relation with environmental parameters}

It has already been shown that in very dynamic zones like estuaries, the distribution of TEP may be mainly controlled by environmental processes (Malpezzi et al. 2013). In the literature, TEP production has been frequently associated with nutrient stress (Corzo et al. 2000; Passow 2002). However, the estuarine systems are not nutrient limited, but high values of [TEP] were recorded (Tab. 1). This result confirms that TEP production can be high in nutrient replete conditions as already reported (Claquin et al. 2008; Pedrotti et al. 2010). Thus in the present study, it is possible that the [TEP] dynamics were not associated with nutrient limitation as often cited in the literature but with other processes such as temperature (Claquin et al. 2008) or turbulence intensity (Pedrotti et al. 2010).

The [TEP] measured in the Seine estuary during this survey $(0.52-68.7 \mathrm{mgXGeq} / \mathrm{L}$; Tab. 1) was higher than those reported in the literature, which never exceeded $11 \mathrm{mgXGeq} / \mathrm{L}$ (Passow 2002), 2.82 mgXGeq/L (Malpezzi et al. 2013), $14.8 \mathrm{mgXGeq} / \mathrm{L}$ (Radić et al. 2005) or $1.54 \mathrm{mgXGeq} / \mathrm{L}$ (Annane et al. 2015). Villacorte et al. (2015) investigated the difference in measurements in TEP (>0.4 $\mu \mathrm{m})$ and TEP with $\mathrm{TEP}_{\text {precusors }}(<0.4 \mu \mathrm{m})$ and showed that [TEP] could represent about $11 \%$ of

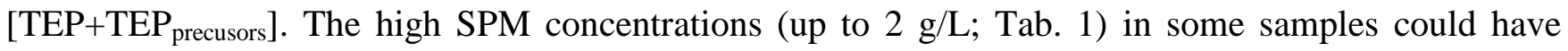
allowed the retention of the $\mathrm{TEP}_{\text {precursors }}$ on the filters thereby partly explaining the very high values observed along the Seine estuary. 
described role of TEP and EPS in particle aggregation and sedimentation processes (Passow 2002;

Thornton 2002). In estuaries, very high TEP concentrations have also been measured in association with

SPM in the MTZ and shown to account for a significant proportion of the POC in MTZ (Malpezzi et al.

2013; Annane et al. 2015). Indeed, because of their sticky properties (Engel 2000; Passow 2002), TEP, associated with a strong salinity gradient and turbulence, promote the aggregation and sedimentation of organic and mineral particles especially within the MTZ and hence influence the dynamics of POM and SPM in the estuary. These processes could explain the distribution of TEP at spatial scale with high concentrations recorded in the MTZ (Tab. 1). In addition, the mixing of freshwater and seawater affects the concentration of some ions and cations responsible for salinity, which could play a major role in the crosslinking of polysaccharides to form gel-like particles such as TEP (Bar-Zeev et al. 2015). This form of TEP formation could reinforce the high [TEP] recorded in the estuary and explain part of the positive relationship with SPM associated with a negative relationship with salinity (Fig. 6). Indeed, due to promotes TEP at MTZ level.

At the daily scale, the high concentrations of TEP in the Seine estuary were mainly linked to tidal flows and mainly recorded within the Seine river plume or the MTZ (Fig. 4), which are both subject to high levels of turbulence leading to resuspension of exopolysaccharide-rich particles from the sediment. At the seasonal scale, the highest concentrations of TEP were recorded during the winter period throughout the salinity gradient (Tab. 1). This seasonal dynamics could be related to higher hydrodynamics in winter, triggered by the combination of strong currents along the estuary during this high flow period and the frequent stormy and windy conditions in this season. These strong hydrodynamics cause higher levels of sediment resuspension from the WSI in winter than in summer.

The S-EPS distribution in the Seine estuary could also be linked to environmental processes. At daily scale, no clear pattern emerged from the S-EPS concentration due to the high variability of the values measured (Fig. 5). However, some peaks were observable both in sub-surface waters and close to the WSI especially at the beginning or end of the flows. This observation suggests that the distribution of S- 
EPS could also be related to resuspension especially before or after tide slacks. At the seasonal scale, the S-EPS were also higher in winter and highest close to the WSI (Tab. 1) thus possibly reinforcing the influence of environmental parameters on S-EPS distribution in the Seine estuary. However, at spatial scale, the concentrations of S-EPS were not linked to the MTZ, like the TEP concentrations, and no relationship was observed with the SPM concentration. This observation suggests that the adsorption characteristics of those S-EPS were lower than TEP. In comparison with TEP, S-EPS easily dissolves in water so their adsorption in the water column could be limited and their concentration more closely linked to biological parameters (De Brouwer et al. 2002). Despite the fact that environmental processes play an important role in distributions of both TEP and S-EPS in the Seine estuary, these processes are mainly produced by biological organisms and the concentrations of those polysaccharides in relation to biological parameters remain to be investigated.

\subsection{Dynamics of EPS in the Seine estuary in relation with biological parameters}

The TEP is mainly produced by phytoplankton and significant correlations between TEP concentrations and phytoplankton dynamics have already been described (Hong 1997; Beauvais et al. 2003; Radić et al. 2005; Wurl and Holmes 2008; Klein et al. 2011). Nevertheless, some studies found no direct correlation between the TEP fraction and chla (Garcia 2002; Corzo et al. 2005). In the present study, a negative correlation was found between TEP and chla (Fig. 6). Our results are comparable with those of Chowdhury et al. (2016) and Klein et al. (2011), who reported low concentrations of TEP during maximum abundance of phytoplankton and higher concentrations during phytoplankton senescence which, in estuaries, is especially important in the MTZ. Moreover, our TEP:chla ratios were inversely correlated with chla and productivity. This observation suggests that the stress generated in the estuary leads to high levels of TEP excretion by the phytoplankton. This hypothesis is supported by the negative correlation between $[\mathrm{TEP}]$ and $\mathrm{F}_{\mathrm{V}} / \mathrm{F}_{\mathrm{M}}$. However, the TEP:chla ratios observed in this study (Tab. 1) are also high in comparison with those previously reported in the literature (Passow 2002; Klein et al. 2011). Therefore, the [TEP] may not be only linked to phytoplankton production. However, the TEP:chla ratios observed in this study (Tab. 1) are also high in comparison with those previously 
reported in the literature (Passow 2002; Klein et al.2011). Therefore, the [TEP] may not be only linked

to phytoplankton production. In strong hydrodynamic conditions, the high [TEP] in the MTZ may also be attributed to the microbial loop activity. Indeed, it has been shown that the POM from the MTZ is biodegraded by highly active heterotrophic bacteria that can also release TEP into the water column (Azam et al. 1983; Middelburg and Herman 2007; Malpezzi et al. 2013). Moreover, significant quantities of TEP could be derived from allochthonous inputs of organic matter that include high concentrations of detrital material and heterotrophic bacteria (Heip et al. 1995).

S-EPS produced by phytoplankton are known to protect cells against digestive enzymes, toxic substances (Wotton 2004), and osmotic stress (Liu and Buskey 2000), which is a major constraint in estuaries. Additionally, S-EPS can be produced by phytoplankton in aiding in flotation process through their threads and by reducing density (Wotton 2004). These potential roles of S-EPS could explain the high concentrations observed in this study (Tab. 1) especially during flows (Fig. 5). In addition to chla dynamics, changes in carbon excretion and photosynthetic parameters can may also be due to different phytoplankton assemblages combined with water mass dynamics (Klein et al. 2011). However, no relationship was found with the $\mathrm{F}_{\mathrm{V}} / \mathrm{F}_{\mathrm{M}}$, and S-EPS concentrations were negatively correlated with chla concentrations and productivity, which confirm results of previous studies (Passow 2002; Klein et al. 2011) showing that, in contrast to TEP, a large proportion of the S-EPS pools were not related to phytoplankton dynamics.

\subsection{Potential contribution of allochthonous primary producers to the S-EPS pool}

Both groups of phototrophic microorganisms (phytoplankton and microphytobenthos) excrete S-EPS for different reasons and in different ways. Due to the key roles played by EPS in epipelic diatom dynamics in mobility and substratum adhesion, the S-EPS dynamics in ecosystems have often been linked with microphytobenthos cells. However, in the Seine estuary the surface of mudflat during low tide represents only $7.21 \%$ of the estuarine surface and no subtidal microphytobenthos community exists because of the high level of turbidity and the depth (up to $18 \mathrm{~m}$ ). Additionally, the mudflat is a plane system and microphytobenthos are especially active during emersion during the daylight period 
whereas the pelagic system is volumetric: in the Seine estuary for a mudflat surface of $7.6 \times 10^{6} \mathrm{~m}^{2}$, the

water volume is $930 \times 10^{6} \mathrm{~m}^{3}$ (on average between low and high tides).

We estimated potential S-EPS production by the microphytobenthic compartment using the data we sampled in the intertidal zones (Morelle et al, in prep) and a microphytobenthic EPS production coefficient estimated at $1.8 \mathrm{mgGeq} / \mathrm{mgchl} / \mathrm{h}$ (Wolfstein et al. 2002). Assuming a tidal emersion during daylight of 6 hours per day and a maximum residence time of 18 days in the Seine estuary (Brenon and Hir 1999; Even et al. 2007), the S-EPS pool originating from microphytobenthos represents $0.055 \pm$ $0.054 \mathrm{mgGeq} / \mathrm{L}$ in the water column. The percentage of S-EPS originating from microphytobenthos production could represent an average of $1.61 \%$ of the mean S-EPS pool measured during this survey. In the same way, we estimated potential phytoplankton S-EPS production using a production coefficient $40 \%$ lower than microphytobenthos production (Goto et al. 1999), i.e. $1.08 \mathrm{mgGeq} / \mathrm{mgchla} / \mathrm{h}$. The SEPS pool originating from phytoplankton represent $1.15 \pm 1.54 \mathrm{mgGeq} / \mathrm{L}$ in the water column. On average, the percentage of EPS originating from phytoplankton production could represent $33.62 \%$ of the mean S-EPS pool measured during this survey. However, we used a maximum residence time of 18 days whereas in reality, the residence time ranged between 5 and 18 days. If we used the minimum residence time of 5 days, the percentage would be $9.34 \%$ for the phytoplankton and $0.44 \%$ for the microphytobenthos. In addition, if we consider that, in exceptional conditions, all the S-EPS pool present on mudflats could be re-suspended in the water column each day, considering 5 to 18 days residence time, the percentage of S-EPS from microphytobenthos production could represent from 1.70 to $6.14 \%$ of the mean S-EPS pool measured in the water column. Thus, we suggest that part of [S-EPS] in the Seine estuary is not directly linked to primary producers. In addition to hydrodynamic processes of remobilization from sediments and upstream inputs, other organisms such as zoo-plankton, zoobenthos, and especially bacteria could contribute significantly to the S-EPS pool. Further studies are therefore needed to understand the origin of the S-EPS in highly hydrodynamic estuaries.

\section{Conclusion}


614 living cells with good physiological status in the bottom water layers pointing to a role for this fraction 615 in the autochthonous production of this estuary. This finding has major implications for trophic transfer 616 between pelagic and benthic organisms, which plays a key role in the nursery and feeding function of 617 these ecosystems.

618 We also showed that EPS are not only linked to primary production processes but rather to stress 619 levels (salinity, turbidity, temperature or hydrodynamics), demonstrating that healthy phytoplankton 620 produce less EPS than stressed or senescent cells. EPS distributions especially TEP are thus mainly linked to hydrodynamic processes such as MTZ formation or sediment resuspension. Our estimation of the relative contribution of primary producers (phytoplankton and microphytobenthos) to S-EPS production show that the mudflats contribute less than $6 \%$ to the S-EPS pool in the water column, while phytoplankton produce up to $33 \%$. The origin of a large proportion of the S-EPS in the water column thus remains unknown and further investigation is needed into potential secondary production of S-EPS by zoobenthos, zooplankton and heterotrophic microbial communities.

\section{Acknowledgments}

The authors wish to thank Romaric Verney and Matthias Jacquet from IFREMER/Brest for inviting us to their campaigns of the "SUSPENS" project, their CTD casts and the realization of the SPM

\section{References}

Adolf, J. E., C. L. Yeager, W. D. Miller, M. E. Mallonee, and L. W. Harding. 2006. Environmental forcing of phytoplankton floral composition, biomass, and primary productivity in Chesapeake Bay, USA. Estuarine, Coastal and Shelf Science 67: 108-122.

Alpine, A. E., and J. E. Cloern. 1992. Trophic interactions and direct fhysical effects control 
fhytoplankton biomass and production in an estuary. Limnology and Oceanography 37: 946-955.

Aminot, A., and R. Kérouel. 2004. Hydrologie des écosystèmes marins: paramètres et analyses, Editions Quae.

Aminot, A., and R. Kérouel. 2007. Dosage automatique des nutriments dans les eaux marines. Méthodes d'analyse en milieu marin

Annane, S., L. St-Amand, M. Starr, E. Pelletier, and G. A. Ferreyra. 2015. Contribution of transparent exopolymeric particles (TEP) to estuarine particulate organic carbon pool. Marine Ecology Progress Series 529: 17-34.

Ayadi, H., O. Abid, J. Elloumi, A. Bouaïn, and T. Sime-Ngando. 2004. Structure of the phytoplankton communities in two lagoons of different salinity in the Sfax saltern (Tunisia). Journal of Plankton Research 26: 669-679.

Azam, F., T. Fenchel, J. G. Field, J. S. Graf, M.-R. L. A, and Thingstad F. 1983. The Ecological Role of Water-Column Microbes in the Sea. Marine Ecology 10: 257-263.

Bar-Zeev, E., U. Passow, S. Romero-Vargas Castrillón, and M. Elimelech. 2015. Transparent exopolymer particles: From aquatic environments and engineered systems to membrane biofouling. Environmental Science and Technology 49: 691-707.

Barbier, E., and S. Hacker. 2011. The value of estuarine and coastal ecosystem services. Ecological Monographs 81: 169-193.

Barranguet, C., and J. Kromkamp. 2000. Estimating primary production rates from photosynthetic electron transport in estuarine microphytobenthos. Marine Ecology Progress Series 204: 39-52.

Beauvais, S., M. L. Pedrotti, E. Villa, and R. Lemée. 2003. Transparent exopolymer particle (TEP) dynamics in relation to trophic and hydrological conditions in the NW Mediterranean Sea. Marine Ecology Progress Series 262: 97-109.

Bhaskar, P. V, and N. B. Bhosle. 2005. Microbial extracellular polymeric substances in marine biogeochemical processes. Current Science $\mathbf{8 8}$.

Brenon, I., and P. Le Hir. 1999. Modelling the Turbidity Maximum in the Seine Estuary ( France ): Identification of Formation. 525-544.

De Brouwer, J. F. C., G. K. Ruddy, T. E. R. Jones, and L. J. Stal. 2002. Sorption of EPS to sediment particles and the effect on the rheology of sediment slurries. Biogeochemistry 61: 57-71.

Cai, W.-J., M. Dai, Y. Wang, W. Zhai, T. Huang, S. Chen, F. Zhang, Z. Chen, and Z. Wang. 2004. The biogeochemistry of inorganic carbon and nutrients in the Pearl River estuary and the adjacent Northern South China Sea. Continental Shelf Research 24: 1301-1319.

Campbell, D. A., V. Hurry, a K. Clarke, P. Gustafsson, and G. Oquist. 1998. Chlorophyll fluorescence analysis of cyanobacterial photosynthesis and acclimation. Microbiology and molecular biology reviews : MMBR 62: 667-683.

Chiovitti, A., P. Molino, S. A. Crawford, R. Teng, T. Spurck, and R. Wetherbee. 2004. The glucans extracted with warm water from diatoms are mainly derived from intracellular chrysolaminaran and not extracellular polysaccharides. European Journal of Phycology 39: 117-128.

Chowdhury, C., N. Majumder, and T. K. Jana. 2016. Seasonal distribution and correlates of transparent exopolymer particles (TEP) in the waters surrounding mangroves in the Sundarbans. Journal of Sea Research 112: 65-74.

Claquin, P., J. C. Kromkamp, and V. Martin-Jezequel. 2004. Relationship between photosynthetic metabolism and cell cycle in a synchronized culture of the marine alga Cylindrotheca fusiformis (Bacillariophyceae). European Journal of Phycology 39: 33-41.

Claquin, P., I. Probert, S. Lefebvre, and B. Veron. 2008. Effects of temperature on photosynthetic parameters and TEP production in eight species of marine microalgae. Aquatic Microbial Ecology 51: $1-11$.

Cloern, J. E. 1991. Tidal stirring and phytoplankton bloom dynamics in an estuary. Journal of Marine Research 49: 203-221.

Cloern, J. E. 1996. Phytoplankton bloom dynamics in coastal ecosystems: A review with some general lessons from sustained investigation of San Francisco Bay, California. Reviews of Geophysics 34: $127-168$.

Cloern, J. E., B. E. Cole, R. L. J. Wong, and A. E. Alpine. 1985. Temporal dynamics of estuarine 
phytoplankton: A case study of San Francisco Bay. Hydrobiologia 129: 153-176.

Cloern, J. E., S. Q. Foster, and a. E. Kleckner. 2014. Phytoplankton primary production in the world's estuarine-coastal ecosystems. Biogeosciences 11: 2477-2501.

Cloern, J. E., and A. D. Jassby. 2010. Patterns and Scales of Phytoplankton Variability in EstuarineCoastal Ecosystems. Estuaries and coasts 33: 230-241.

Corzo, A., J. A. Morillo, and S. Rodríguez. 2000. Production of transparent exopolymer particles (TEP) in cultures of Chaetoceros calcitrans under nitrogen limitation. Aquatic Microbial Ecology 23: 6372.

Corzo, A., S. Rodriguez-Galvez, L. Lubian, P. Sangra, A. Martinez, and J. A. Morillo. 2005. Spatial distribution of transparent exopolymer particles in the Bransfield Strait, Antarctica. Journal of Plankton Research 27: 635-646.

Decho, A. W. 2000. Microbial biofilms in intertidal systems: an overview. Cont. Shelf Res. 20: 12571273.

Desmit, X., J. P. Vanderborght, P. Regnier, and R. Wollast. 2005. Control of phytoplankton production by physical forcing in a strongly tidal, well-mixed estuary. Biogeosciences Discussions 2: 37-75.

Dubois, M., K. A. Gilles, J. K. Hamilton, Pa. Rebers, and F. Smith. 1956. Colorimetric method for determination of sugars and related substances. Analytical chemistry 28: 350-356.

Eilers, P. H. C., and J. C. H. Peeters. 1988. A model for the relationship between light intensity and the rate of photosynthesis in phytoplankton. Ecological Modelling 42: 199-215.

Engel, A. 2000. The role of transparent exopolymer particles (TEP) in the increase in apparent particle stickiness (alpha) during the decline of a diatom bloom. Journal of Plankton Research 22: 485497.

Engel, A., and U. Passow. 2001. Carbon and nitrogen content of transparent exopolymer particles (TEP) in relation to their Alcian Blue adsorption. Marine Ecology Progress Series 219: 1-10.

Etcheber, H., A. Taillez, G. Abril, J. Garnier, P. Servais, F. Moatar, and M. V. Commarieu. 2007. Particulate organic carbon in the estuarine turbidity maxima of the Gironde, Loire and Seine estuaries: Origin and lability. Hydrobiologia 588: 245-259.

Even, S., J. M. Mouchel, P. Servais, N. Flipo, M. Poulin, S. Blanc, M. Chabanel, and C. Paffoni. 2007. Modelling the impacts of Combined Sewer Overflows on the river Seine water quality. Science of the Total Environment 375: 140-151.

Fukao, T., K. Kimoto, T. Yamatogi, K. I. Yamamoto, Y. Yoshida, and Y. Kotani. 2009. Marine mucilage in Ariake Sound, Japan, is composed of transparent exopolymer particles produced by the diatom Coscinodiscus granii. Fisheries Science 75: 1007-1014.

Gameiro, C., and V. Brotas. 2010. Patterns of Phytoplankton variability in the Tagus estuary (Portugal). Estuaries and Coasts 33: 311-323.

Garcia, C. M. 2002. Hydrodynamics and the spatial distribution of plankton and TEP in the Gulf of Cadiz (SW Iberian Peninsula). Journal of Plankton Research 24: 817-833.

Garnier, J., G. Billen, J. Némery, and M. Sebilo. 2010. Transformations of nutrients (N, P, Si) in the turbidity maximum zone of the Seine estuary and export to the sea. Estuarine, Coastal and Shelf Science 90: 129-141.

Genty, B., J. Harbinson, J. Briantais, N. R. Baker, and C. Lane. 1989. The relationship between nonphotochemical quenching of chlorophyll fluorescence and the rate of photosystem 2 photochemistry in leaves. Photosynthesis research 25: 249-257.

Glover, H. E., D. A. Phinney, and C. S. Yentsch. 1985. Photosynthetic characteristics of picoplankton compared with those of larger phytoplankton populations, in various water masses in the Gulf of Maine. Deep Sea Research Part B. Oceanographic Literature Review 32: 759.

Goto, N., T. Kawamura, O. Mitamura, and H. Terai. 1999. Importance of extracellular organic carbon production in the total primary production by tidal-flat diatoms in comparison to phytoplankton. Marine Ecology Progress Series 190: 289-295.

Heip, C. H. R., N. K. Goosen, P. M. J. Herman, J. Kromkamp, J. J. Middelburg, and K. Soetaert. 1995. Production and consumption of biological particles in temperate tidal estuaries,.

Hernando, M., I. R. Schloss, G. Malanga, G. O. Almandoz, G. A. Ferreyra, M. B. Aguiar, and S. Puntarulo. 2015. Effects of salinity changes on coastal Antarctic phytoplankton physiology and 
assemblage composition. Journal of Experimental Marine Biology and Ecology 466: 110-119.

Higgins, T. G. O., S. P. Ferraro, D. D. Dantin, and S. J. Jordan. 2010. Habitat Scale Mapping of Fisheries Ecosystem Service Values in. Ecology and Society 15(4).

Le Hir, P., A. Ficht, R. S. Jacinto, P. Lesueur, J.-P. Dupont, R. Lafite, I. Brenon, B. Thouvenin, and P. Cugier. 2001. Fine Sediment Transport and Accumulations at the Mouth of the Seine Estuary (France). Estuaries 24: 950.

Hong, Y. 1997. Studies on Transparent Exopolymer Particles (Tep) Produced in the Ross Sea (Antarctica) and By Phaeocystis Antarctica (Prymnesiophyceae). 376: 368-376.

Hydes, D., M. Aoyama, A. Aminot, K. Bakker, S. Becker, S. Coverly, A. Daniel, A. G. Dickson, O. Grosso, R. Kerouel, J. van Ooijen, K. Sato, T. Tanhua, E. M. S. Woodward, and J. Z. Zhang. 2010. Determination of dissolved nutrients $(\mathrm{N}, \mathrm{P}, \mathrm{Si})$ in seawater with high precision and intercomparability using gas-segmented continuous flow analysers. The GO-SHIP Repeat Hydrography Manual IOCCP Report 134: 1-87.

Josselyn, M. N., and J. A. West. 1985. Temporal Dynamics of an Estuary: San Francisco Bay, p. 139152. In J.E. Cloern and F.H. Nichols [eds.]. Springer Netherlands.

Jouenne, F., S. Lefebvre, B. Véron, and Y. Lagadeuc. 2007. Phytoplankton community structure and primary production in small intertidal estuarine-bay ecosystem (eastern English Channel, France). Marine Biology 151: 805-825.

Juneau, P., and P. J. Harrison. 2005. Comparison by PAM Fluorometry of Photosynthetic Activity of Nine Marine Phytoplankton Grown Under Identical Conditions. photochemistry and photobiology 649-653.

Kaiser, M. J. 2011. Marine ecology: processes, systems, and impacts, Oxford University Press.

Klein, C., P. Claquin, P. Alexandrine, C. Napoléon, B. Le Roy, and B. Véron. 2011. Dynamics of soluble extracellular polymeric substances and transparent exopolymer particle pools in coastal ecosystems. Marine Ecology Progress Series 427: 13-27.

Kolber, Z., and P. G. Falkowski. 1993. Use of active fluorescence to estimate phytoplankton photosynthesis in situ. Limnology and Oceanography 38: 1646-1665.

Kromkamp, J. C., and R. M. Forster. 2003. The use of variable fluorescence measurements in aquatic ecosystems : differences between multiple and single turnover measuring protocols and suggested terminology. European Journal of Phycology 38: 103-112.

Kromkamp, J., J. Peene, P. van Rijswijk, A. Sandee, and N. Goosen. 1995. Nutrients, light and primary production by phytoplankton and microphytobenthos in the eutrophic, turbid Westerschelde estuary (The Netherlands). Hydrobiologia 311: 9-19.

Lehman, P. W. 2007. The influence of phytoplankton community composition on primary productivity along the riverine to freshwater tidal continuum in the San Joaquin River, California. Estuaries and Coasts 30: 82-93.

Lionard, M., K. Muylaert, D. Van Gansbeke, and W. Vyverman. 2005. Influence of changes in salinity and light intensity on growth of phytoplankton communities from the Schelde river and estuary (Belgium/The Netherlands). Hydrobiologia 540: 105-115.

Liu, H., and E. J. Buskey. 2000. Hypersalinity Enhances the Production of Extracellular Polymeric. Production 77: 71-77.

Lorenzen, C. J. 1966. A method for the continuous measurement of in vivo chlorophyll concentration. Deep Sea Research and Oceanographic Abstracts 13: 223-227.

Macintyre, H. L., T. M. Kana, T. Anning, and R. J. Geider. 2002. Review Photoacclimatation of photosynthesis Irradiance response curves and photosynthetic pigments in microalgae and cyanobacteria. Journal of Phycology 38: 17-38.

Malpezzi, M. A., L. P. Sanford, and B. C. Crump. 2013. Abundance and distribution of transparent exopolymer particles in the estuarine turbidity maximum of Chesapeake Bay. Marine Ecology Progress Series 486: $23-35$.

Masojidek, J., J. Grobbelaar, L. Pechar, and M. Koblizek. 2001. Photosystem II electron transport rates and oxygen production in natural waterblooms of freshwater cyanobacteria during a diel cycle. Journal of Plankton Research 23: 57-66.

Middelburg, J. J., and P. M. J. Herman. 2007. Organic matter processing in tidal estuaries. Marine 
Chemistry 106: 127-147.

Monbet, Y. 1992. Control of Phytoplankton Biomass in Estuaries: A Comparative Analysis of Microtidal and Macrotidal Estuaries. Estuaries 15: 563.

Morse, R. E., M. R. Mulholland, T. A. Egerton, and H. G. Marshall. 2014. Phytoplankton and nutrient dynamics in a tidally dominated eutrophic estuary: Daily variability and controls on bloom formation. Marine Ecology Progress Series 503: 59-74.

Muylaert, K., K. Sabbe, and W. Vyverman. 2009. Changes in phytoplankton diversity and community composition along the salinity gradient of the Schelde estuary (Belgium/The Netherlands). Estuarine, Coastal and Shelf Science 82: 335-340.

Napoleon, C., V. Raimbault, L. Fiant, P. Riou, S. Lefebvre, L. Lampert, and P. Claquin. 2012. Spatiotemporal dynamics of physicochemical and photosynthetic parameters in the central English Channel. Journal of Sea Research 69: 43-52.

Némery, J., and J. Garnier. 2007. Origin and fate of phosphorus in the Seine watershed (France): Agricultural and hydrographic P budgets. Journal of Geophysical Research: Biogeosciences 112: $1-14$.

Orvain, F., M. De Crignis, K. Guizien, S. Lefebvre, C. Mallet, E. Takahashi, and C. Dupuy. 2014. Tidal and seasonal effects on the short-term temporal patterns of bacteria, microphytobenthos and exopolymers in natural intertidal biofilms (Brouage, France). Journal of Sea Research , doi:10.1016/j.seares.2014.02.018

Parizzi, R. A., E. Da, C. Machado, C. Prestes, D. Santos, L. F. Fernandes, M. G. De Camargo, L. Laureno, and M. Jr. 2016. Primary productivity and phytoplankton dynamics in a subtropical estuary : a multiple timescale approach. Scientia Marina 80: 1-13.

Passow, U. 2002. Transparent exopolymer particles (TEP) in aquatic environments. Progress in Oceanography 55: 287-333.

Passow, U., and A. L. Alldredge. 1995. A dye-binding assay for the spectrophotometric measurement of transparent exopolymer particles (TEP). Limnology and Oceanography 40: 1326-1335.

Passow, U., R. F. Shipe, A. Murray, D. K. Pak, M. A. Brzezinski, and A. L. Alldredge. 2001. The origin of transparent exopolymer particles (TEP) and their role in the sedimentation of particulate matter. Continental Shelf Research 21: 327-346.

Passy, P., R. Le Gendre, J. Garnier, P. Cugier, J. Callens, F. Paris, G. Billen, P. Riou, and E. Romero. 2016. Eutrophication modelling chain for improved management strategies to prevent algal blooms in the Bay of Seine. Marine Ecology Progress Series 543: 107-125.

Pedrotti, M. L., F. Peters, S. Beauvais, M. Vidal, J. Egge, A. Jacobsen, and C. Marrasé. 2010. Effects of nutrients and turbulence on the production of transparent exopolymer particles: A mesocosm study. Marine Ecology Progress Series 419: 57-69.

Porter, E. M., W. D. Bowman, C. M. Clark, J. E. Compton, L. H. Pardo, and J. L. Soong. 2013. Interactive effects of anthropogenic nitrogen enrichment and climate change on terrestrial and aquatic biodiversity. Biogeochemistry 114: 93-120.

Radić, T., R. Kraus, D. Fuks, J. Radić, and O. Pečar. 2005. Transparent exopolymeric particles' distribution in the northern Adriatic and their relation to microphytoplankton biomass and composition. Science of the Total Environment 353: 151-161.

Sarma, V., S. N. M. Gupta, P. V. R. Babu, T. Acharya, N. Harikrishnachari, K. Vishnuvardhan, N. S. Rao, N. P. C. Reddy, V. V Sarma, and Y. Sadhuram. 2009. Influence of river discharge on plankton metabolic rates in the tropical monsoon driven Godavari estuary, India. Estuarine, Coastal and Shelf Science 85: 515-524.

Schreiber, U., U. Schliwa, and W. Bilger. 1986. Continuous recording of photochemical and nonphotochemical chlorophyll fluorescence quenching with a new type of modulation fluorometer. Photosynthesis research 10: 51-62.

Servais, P., and J. Garnier. 2006. Organic carbon and bacterial heterotrophic activity in the maximum turbidity zone of the Seine estuary (France). Aquatic Sciences 68: 78-85.

Shaffer, G. P., and C. P. Onuf. 1985. Reducing the error in estimating annual production of benthic microflora: Hourly to monthly rates, patchiness in space and time. Marine Ecology Progress Series 26: $221-231$. 
Statham, P. J. 2012. Nutrients in estuaries - An overview and the potential impacts of climate change. Science of the Total Environment 434: 213-227.

Suggett, D. J., H. L. MacIntyre, and R. J. Geider. 2004. Evaluation of biophysical and optical determinations of light absorption by photosystem II in phytoplankton. Limnology and Oceanography: Methods 2: 316-332.

Sun, C., Y. Wang, Q. P. Li, W. Yue, Y. Wang, F. Sun, and Y. Peng. 2012. Distribution characteristics of transparent exopolymer particles in the Pearl River estuary, China. 117: 1-12.

Takahashi, E., J. Ledauphin, D. Goux, and F. Orvain. 2009. Optimising extraction of extracellular polymeric substances (EPS) from benthic diatoms: comparison of the efficiency of six EPS extraction methods. Marine and Freshwater Research 60: 1201-1210.

Thornton, D. 2002. Diatom aggregation in the sea: mechanisms and ecological implications. European Journal of Phycology 37: 149-161.

Underwood, G. J. C., and J. Kromkamp. 1999. Primary Production by Phytoplankton and Microphytobenthos in Estuaries. Advances in Ecological Research 29: 93-153.

Underwood, G. J. C., D. M. Paterson, and R. J. Parkes. 1995. The measurement of microbial carbohydrate exopolymers from intertidal sediments. Limnol. Oceanogr 40: 1243-1253.

Verney, R., R. Lafite, and J. C. Brun-Cottan. 2009. Flocculation potential of estuarine particles: The importance of environmental factors and of the spatial and seasonal variability of suspended particulate matter. Estuaries and Coasts 32: 678-693.

Viles, H., and T. Spencer. 1995. Coastal Problems: Geomorphology, Ecology and Society at the coast, Edward Arn.

Villacorte, L. O., Y. Ekowati, H. N. Calix-Ponce, J. C. Schippers, G. L. Amy, and M. D. Kennedy. 2015. Improved method for measuring transparent exopolymer particles (TEP) and their precursors infresh and saline water. Water Research 70: 300-312.

Wang, Z. B., M. C. J. L. Jeuken, H. Gerritsen, H. J. De Vriend, and B. A. Kornman. 2002. Morphology and asymmetry of the vertical tide in the Westerschelde estuary. Continental Shelf Research 22: 2599-2609.

Wetz, M. S., M. C. Robbins, and H. W. Paerl. 2009. Transparent exopolymer particles (TEP) in a riverdominated estuary: Spatial-temporal distributions and an assessment of controls upon TEP formation. Estuaries and Coasts 32: 447-455.

Wolfstein, K., J. F. C. De Brouwer, and L. J. Stal. 2002. Biochemical partitioning of photosynthetically fixed carbon by benthic diatoms during short-term incubations at different irradiances. Marine Ecology Progress Series 245: 21-31.

Wotton, R. S. 2004. The essential role of exopolymers (EPS) in aquatic systems. Oceanography and marine biology: an annual review 42: 57-94.

Wurl, O., and M. Holmes. 2008. The gelatinous nature of the sea-surface microlayer. Marine Chemistry 110: 89-97. 


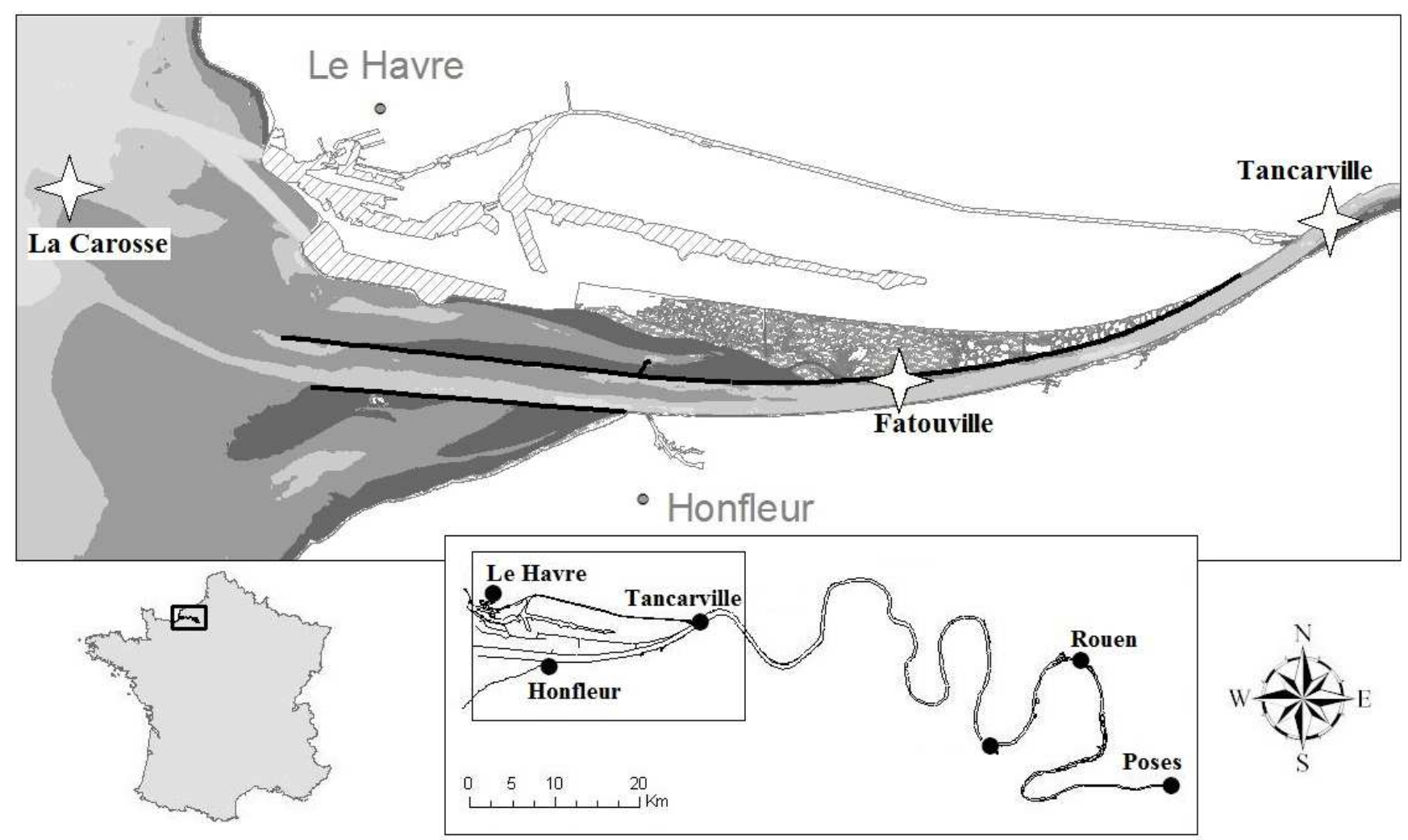

Figure 1. Study area, the Seine Estuary, Normandy, France $\left(\mathbf{4 9}^{\circ} \mathbf{2 6}^{\prime} \mathbf{0 9}{ }^{\prime \prime} \mathbf{N} ; \mathbf{0}^{\circ} \mathbf{1 6}^{\prime 28} 8^{\prime \prime} \mathbf{E}\right)$. Location of the 3 sampling sites (white stars): (i) La Carosse (49 $\left.28^{\circ} 985^{\prime} \mathrm{N} ; 0^{\circ} 01^{\prime} 807^{\prime} \mathrm{E}\right)$, located in the euhaline zone and sampled on February 3 and July 18, (ii) Fatouville $\left(49^{\circ} 26^{\prime} 202^{\prime \prime N}\right.$; $0^{\circ} 19^{\prime} 274^{\prime \prime}$ ), located in the polyhaline zone and sampled on February 4 and July 20 , (iii) Tancarville (49 $24^{\prime} 444^{\prime \prime N}$; $0^{\circ} 28^{\prime} 200^{\prime}$ E), located in the oligohaline zone and sampled on February 5 and July. Black dots represent major cities along the Seine Estuary. 

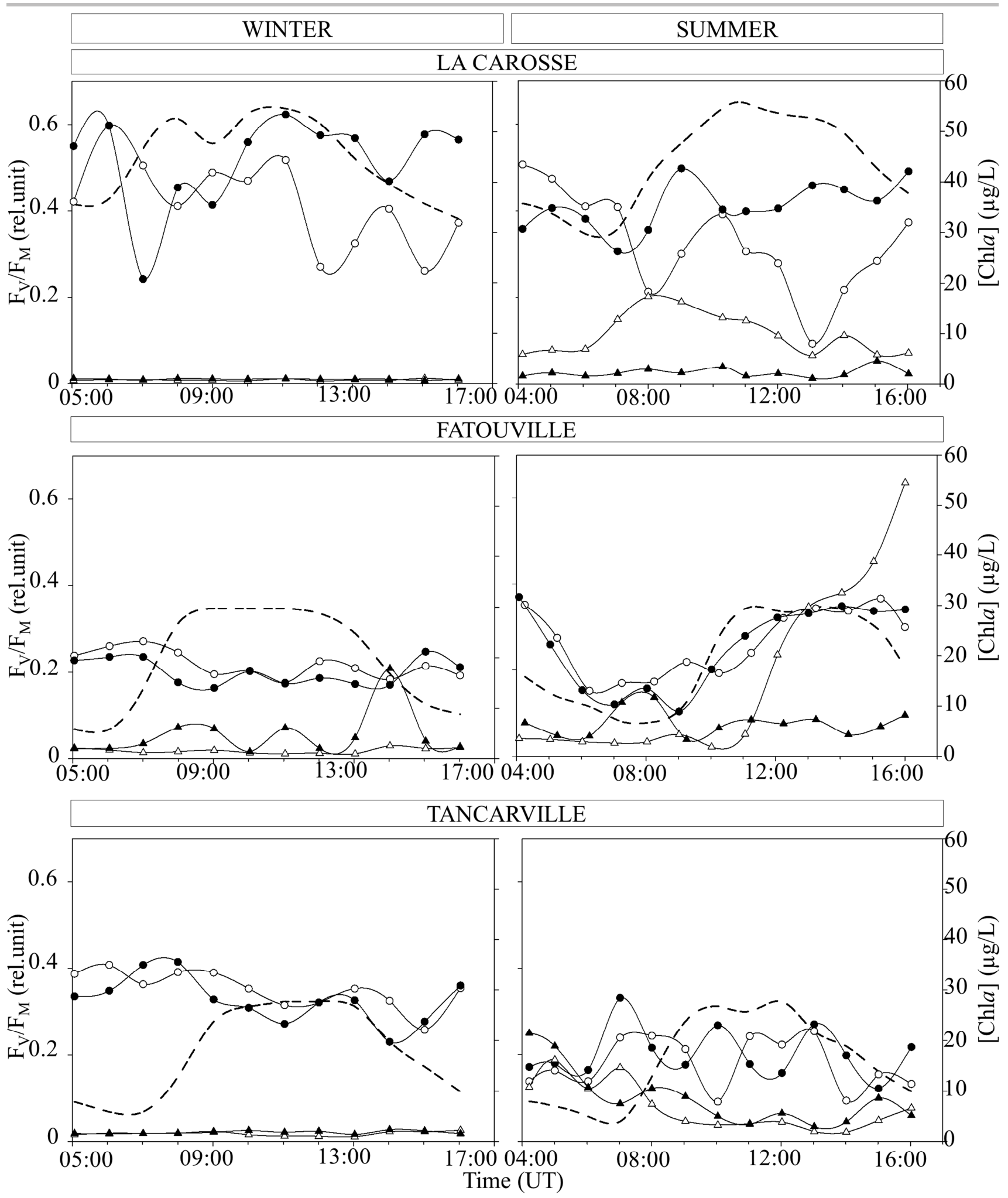

Figure 2. Phytoplankton biomass ([chla], $\mu \mathrm{g} / \mathrm{L}$ - triangles) and $\mathrm{F}_{\mathrm{V}} / \mathrm{F}_{\mathrm{M}}$ (relative units - circles) measured over a tidal cycle at the three sampling sites (La Carosse, Fatouville and Tancarville), in winter (left panel) and in summer (right panel). Values measured $1 \mathrm{~m}$ below the surface are represented by empty circles and values measured $1 \mathrm{~m}$ above the water sediment interface (WSI) by black dots. The dashed lines represent tidal height (m) measured $1 \mathrm{~m}$ above the WSI (cf. Fig. 3). 

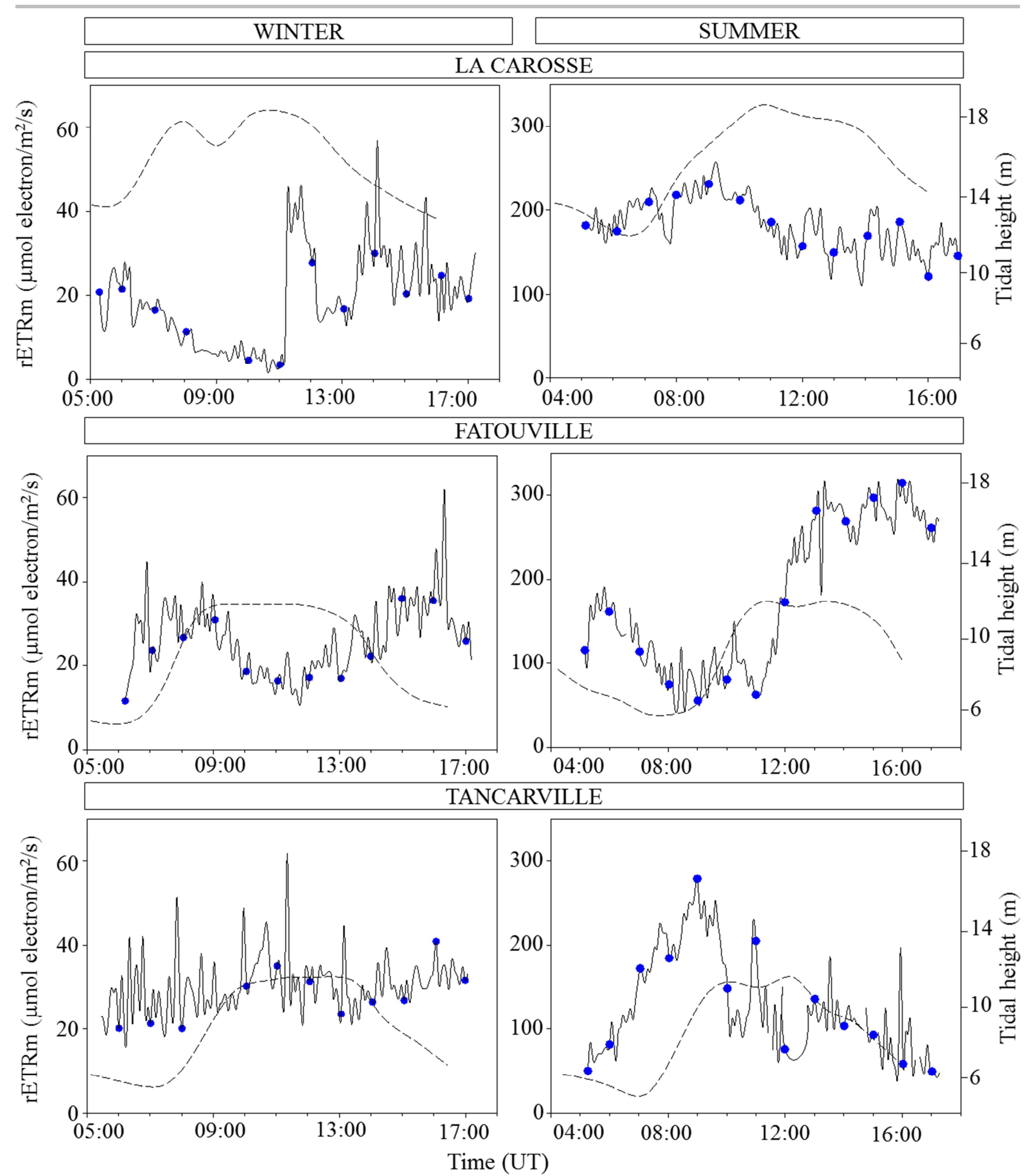

Time (UT)

Figure 3. High frequency measurements of the maximum rate of electron transport $\left(\mathrm{rETR}_{\max } ; \mu \mathrm{mol} \mathrm{electron} / \mathrm{m}^{2} / \mathrm{s}-\right.$ solid line) measured over a tidal cycle at the three sampling sites (La Carosse, Fatouville and Tancarville), in winter (left panel) and in summer (right panel). The dots represent values during low frequency sampling. The dashed lines represent tidal height $(\mathrm{m})$ measured $1 \mathrm{~m}$ above the water sediment interface. 

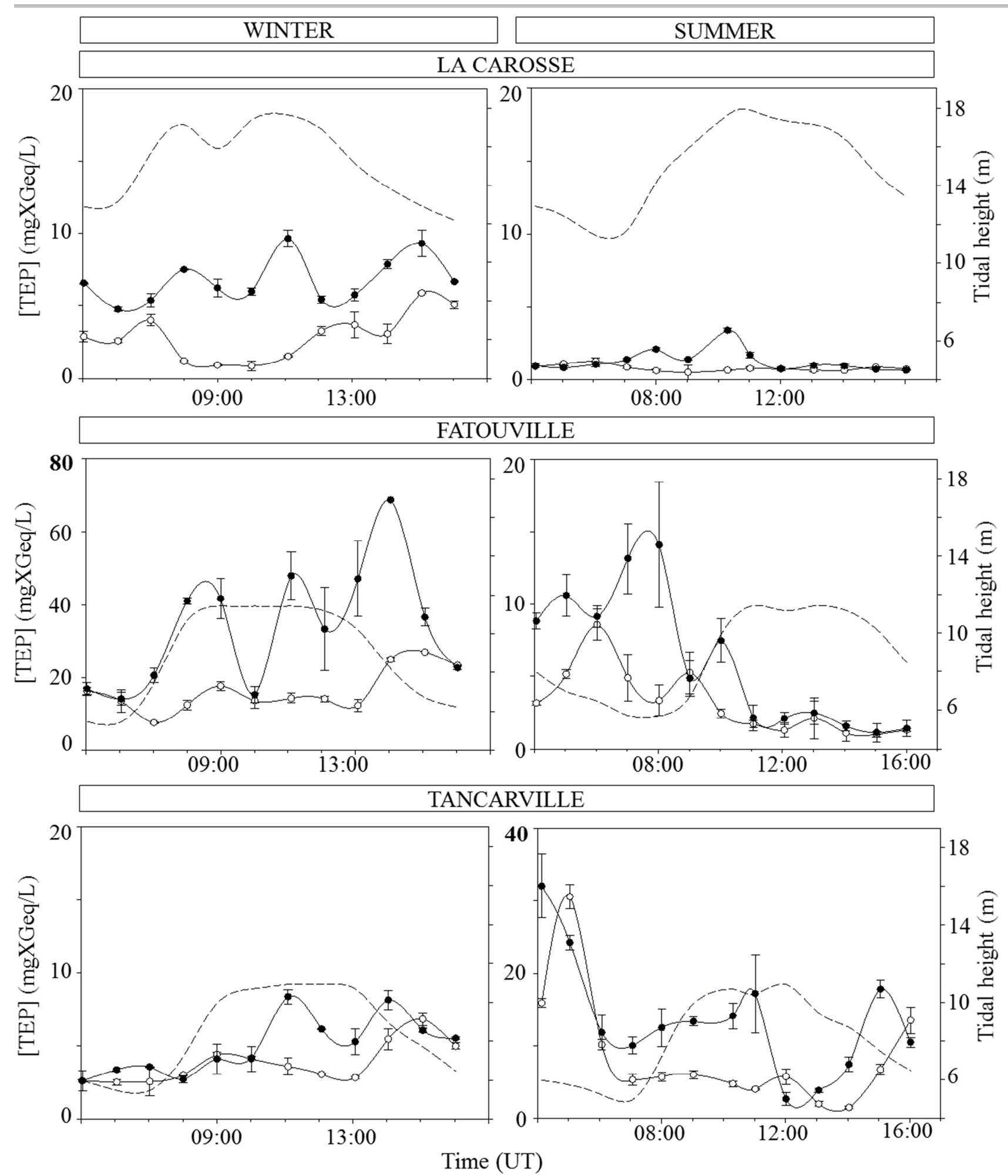

Figure 4. Concentrations of transparent exopolymeric substances ([TEP]; mgXGeq/L; mean \pm standard error) over a tidal cycle at the three sampling sites La Carosse, Fatouville \& Tancarville, in winter (left panel) and in summer (right panel). Values recorded $1 \mathrm{~m}$ below the surface are represented by empty circles and values measured $1 \mathrm{~m}$ above the WSI by black dots. The dashed lines represent the tidal height (m). 

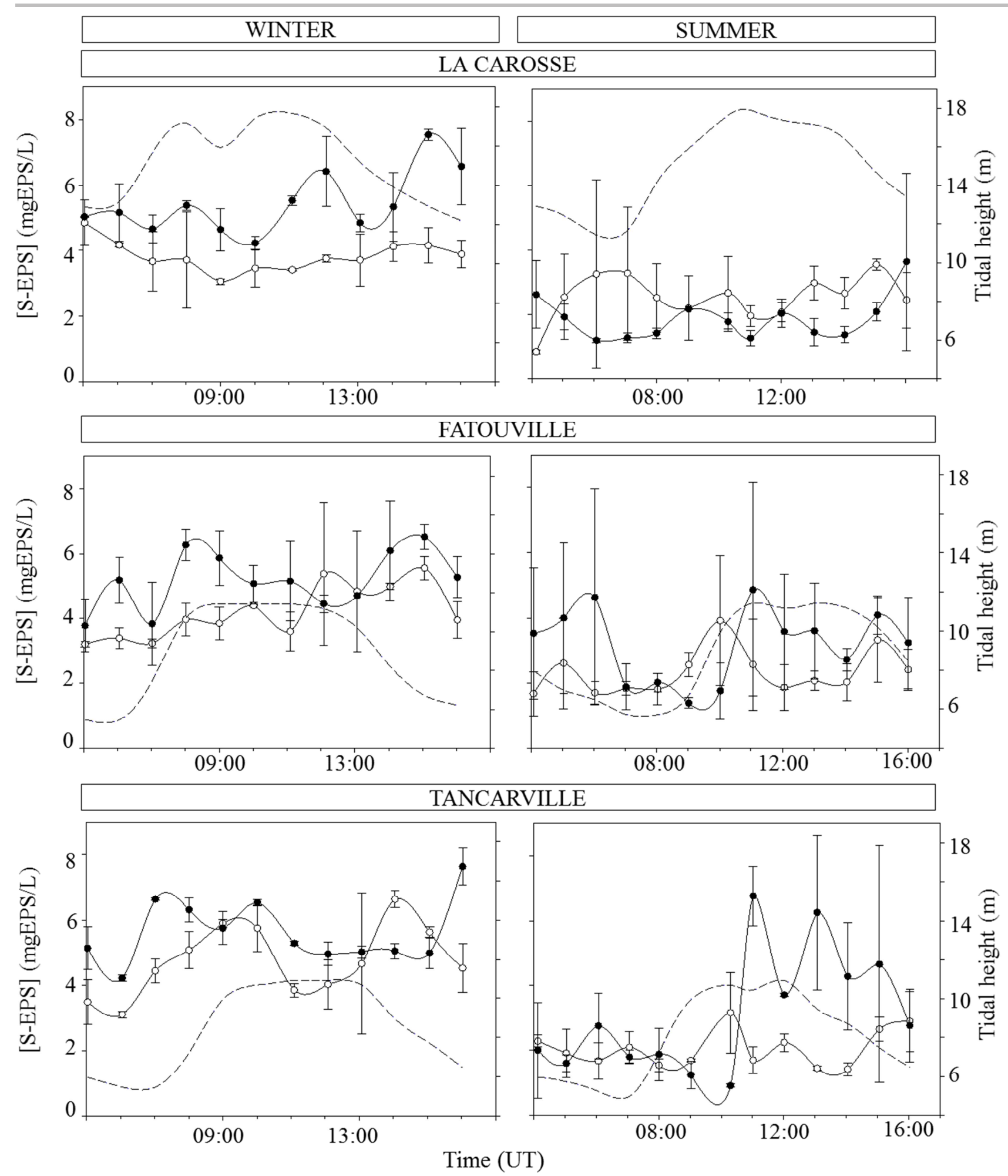

Figure 5. Concentrations of soluble extracellular polymeric substances ([S-EPS]; mgGeq/L; mean \pm standard error) over a tidal cycle at the three sampling sites La Carosse, Fatouville \& Tancarville, in winter (left panel) and in summer (right panel). Values recorded $1 \mathrm{~m}$ below the surface are represented by empty circles and values measured $1 \mathrm{~m}$ above the WSI by black dots. The dashed lines represent the tidal height $(\mathrm{m})$. 

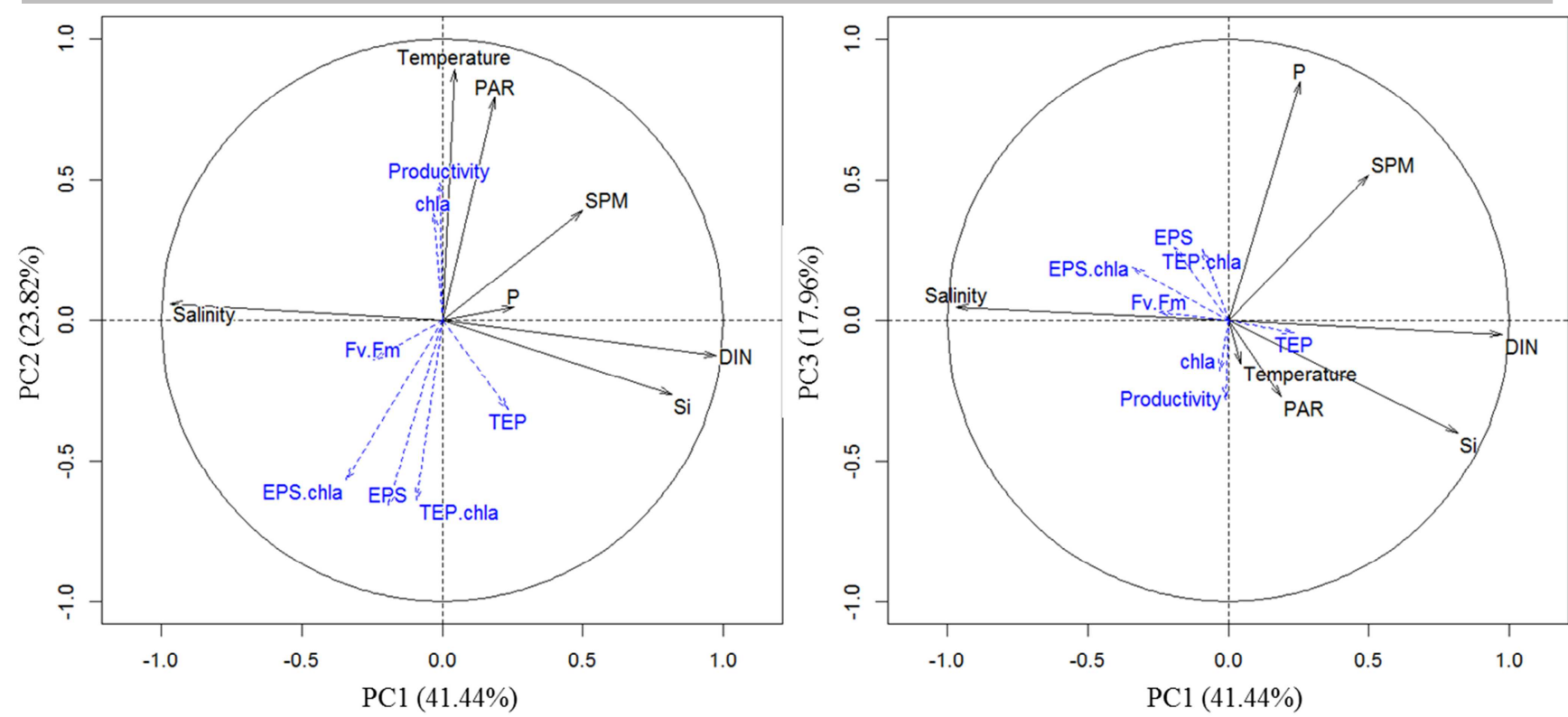

926

Figure 6. Representation of Principal Component Analysis (PCA) using the abiotic parameters $\left(\mathrm{PAR}\left(\mathrm{J} / \mathrm{cm}^{2}\right)\right.$; temperature $\left({ }^{\circ} \mathrm{C}\right)$, salinity (PSU), SPM $(\mathrm{g} / \mathrm{L})$ and nutrients $(\mu \mathrm{mol} / \mathrm{L})$ : DIN, $\mathrm{P}$ and $\mathrm{Si}$ ) and as qualitative variables the biological parameters (chla $(\mu \mathrm{g} / \mathrm{L}), \mathrm{F}_{\mathrm{V}} / \mathrm{F}_{\mathrm{M}}$ (rel.unit), Transparent exopolymeric particles (TEP) \& exopolymeric substances (EPS) concentrations (mgXGeq/L and mgEPS/L) and TEP \& EPS per chl $a$ unit (mgXGeq/mgchla and mgEPS/mgchl $a$ ) as quantitative variables. Dimensions $1 \& 2(65.26 \%)$ in the left panel and the dimensions $1 \& 3(59.40 \%)$ in the right panel. 


\section{Tables}

\section{ACCEPTED MANUSCRIPT}

Table 1. Minimum and maximum values of the sampling parameters recorded at each of the three sites (La Carosse (LC), Fatouville (Fat.) and Tancarville (Tan.)) in sub-surface $(1 \mathrm{~m}$ below the surface $(\mathrm{S}))$ and close to the bottom (1 m above the water sediment interface (B)) in February (winter) and in July (summer) 2015. The S-EPS concentrations are expressed in glucose equivalent (mgGeq) and the TEP concentrations in Xanthan gum equivalent (mgXGeq).

\begin{tabular}{|c|c|c|c|c|c|c|c|c|c|}
\hline Sites & $\mathrm{S} / \mathrm{B}$ & $\begin{array}{c}\mathrm{SPM} \\
\mathrm{g} / \mathrm{L}\end{array}$ & $\begin{array}{l}\text { Chla } \\
\mu \mathrm{g} / \mathrm{L}\end{array}$ & $\underset{\text { ratio }}{\mathrm{F}_{\mathrm{V}} / \mathrm{F}_{\mathrm{M}}}$ & $\underset{\mu \mathrm{rETR}}{\mathrm{rEax}_{\max }}$ & $\begin{array}{c}\text { TEP } \\
\text { mgXGeq/L }\end{array}$ & $\begin{array}{c}\text { TEP:Chla } \\
\left(\times 10^{3}\right) \\
\text { mgXGeq/mgchl } a\end{array}$ & $\begin{array}{c}\text { EPS } \\
\mathrm{mgGeq} / \mathrm{L}\end{array}$ & $\begin{array}{c}\text { EPS:Chla } \\
\text { mgGeq/mgchla }\end{array}$ \\
\hline \multicolumn{10}{|c|}{ Winter } \\
\hline \multirow{2}{*}{$\mathrm{LC}$} & $S$ & $0.01 / 0.11$ & $0.49 / 1.01$ & $0.26 / 0.60$ & $3.52 / 29.95$ & $0.87 / 5.90$ & $1.46 / 8.00$ & $3.06 / 4.85$ & $3.66 / 8.14$ \\
\hline & B & $0.02 / 0.08$ & $0.59 / 0.98$ & $0.24 / 0.62$ & - & $4.76 / 9.65$ & $5.51 / 15.84$ & $4.23 / 7.53$ & $4.93 / 12.81$ \\
\hline \multirow{2}{*}{ Fat. } & $S$ & $0.03 / 1.77$ & $0.97 / 2.55$ & $0.18 / 0.27$ & $11.69 / 47.82$ & $7.57 / 26.94$ & $6.22 / 14.33$ & $3.20 / 5.56$ & $1.51 / 4.99$ \\
\hline & B & $0.08 / 2.81$ & $1.40 / 27.20$ & $0.16 / 0.25$ & - & $14.08 / 68.69$ & $2.53 / 16.14$ & $3.78 / 6.53$ & $0.22 / 3.63$ \\
\hline \multirow{2}{*}{ Tan. } & S & $0.03 / 0.22$ & $1.00 / 2.27$ & $0.26 / 0.41$ & $20.11 / 40.87$ & $2.52 / 6.82$ & $1.50 / 3.42$ & $3.10 / 6.64$ & $1.84 / 4.69$ \\
\hline & $\mathrm{B}$ & $0.07 / 0.44$ & $1.44 / 2.40$ & $0.23 / 0.42$ & - & $2.63 / 8.38$ & $1.60 / 4.48$ & $4.23 / 7.64$ & $2.10 / 4.75$ \\
\hline \multicolumn{10}{|c|}{ Summer } \\
\hline \multirow{2}{*}{$\mathrm{LC}$} & $S$ & $0.00 / 0.02$ & $5.71 / 17.37$ & $0.09 / 0.51$ & $120.81 / 231.03$ & $0.52 / 1.27$ & $0.03 / 0.18$ & $0.85 / 3.54$ & $0.13 / 0.60$ \\
\hline & $\mathrm{B}$ & $0.01 / 0.05$ & $1.17 / 4.61$ & $0.31 / 0.50$ & - & $0.66 / 3.40$ & $0.16 / 1.05$ & $1.20 / 3.63$ & $0.45 / 1.78$ \\
\hline \multirow{2}{*}{ Fat. } & $S$ & $0.02 / 0.43$ & $1.84 / 54.57$ & $0.15 / 0.37$ & $55.84 / 314.65$ & $1.00 / 8.58$ & $0.02 / 2.99$ & $1.67 / 3.92$ & $0.04 / 8.59$ \\
\hline & $\mathrm{B}$ & $0.02 / 0.94$ & $3.33 / 11.72$ & $0.10 / 0.37$ & - & $1.13 / 14.10$ & $0.17 / 2.59$ & $1.38 / 4.87$ & $0.17 / 1.16$ \\
\hline \multirow{2}{*}{ Tan. } & $\mathrm{S}$ & $0.03 / 1.03$ & $1.80 / 16.12$ & $0.09 / 0.25$ & $49.56 / 278.75$ & $1.53 / 30.59$ & $0.37 / 2.06$ & $1.42 / 5.15$ & $0.12 / 1.30$ \\
\hline & B & $0.11 / 2.00$ & $2.88 / 21.45$ & $0.12 / 0.33$ & - & $2.68 / 32.06$ & $0.49 / 5.19$ & $0.91 / 6.77$ & $0.08 / 2.17$ \\
\hline
\end{tabular}

Table 2. Variations in mass of soluble extracellular polymeric substances per $\mathbf{m}^{2}\left(\mathrm{mgEPS} / \mathrm{m}^{2}\right)$ and in EPS:chla ratios (mgEPS/mgchla) at the 15 sites sampled on the Seine estuary mudflats (Morelle et al, in prep.). The S-EPS concentrations are expressed in glucose equivalent $(\mathrm{mgGeq})$ and the TEP concentrations in Xanthan gum equivalent (mgXGeq).

\begin{tabular}{|c|c|c|c|c|c|c|}
\hline \multirow[b]{2}{*}{ Site } & \multirow[b]{2}{*}{$\begin{array}{c}\text { Longitude } \\
\text { (Wgs84) }\end{array}$} & \multirow[b]{2}{*}{$\begin{array}{l}\text { Latitude } \\
\text { (Wgs84) }\end{array}$} & \multicolumn{2}{|c|}{ September, 2014} & \multicolumn{2}{|c|}{ April, 2015} \\
\hline & & & $\begin{array}{c}\text { EPS:chla } \\
(\mathrm{mgGeq} / \mathrm{mgchl} a)\end{array}$ & $\begin{array}{c}\text { EPS } \\
\left(\mathrm{mgGeq} / \mathrm{m}^{2}\right)\end{array}$ & $\begin{array}{c}\text { EPS:chla } \\
(\mathrm{mgGeq} / \mathrm{mgchl} a)\end{array}$ & $\begin{array}{c}\text { EPS } \\
\left(\mathrm{mgGeq} / \mathrm{m}^{2}\right)\end{array}$ \\
\hline $\mathbf{O}$ & 0.2001 & 49.4267 & 1.33 & 87.10 & 33.52 & 149.82 \\
\hline C & 0.2004 & 49.4482 & 33.91 & 480.45 & NA & NA \\
\hline $\mathbf{N}$ & 0.1672 & 49.4162 & 10.78 & 377.18 & 33.78 & 284.73 \\
\hline $\mathbf{E}$ & 0.2174 & 49.4483 & 1.55 & 264.12 & 4.31 & 91.02 \\
\hline $\mathbf{P}$ & 0.2003 & 49.4235 & 5.83 & 197.33 & 92.56 & 149.01 \\
\hline B & 0.2004 & 49.4506 & 5.45 & 409.84 & 11.62 & 227.14 \\
\hline $\mathbf{F}$ & 0.2172 & 49.4462 & 6.95 & 437.90 & 4.99 & 129.03 \\
\hline H & 0.2668 & 49.4408 & 7.19 & 181.99 & 36.78 & 118.06 \\
\hline $\mathbf{G}$ & 0.267 & 49.4436 & 5.09 & 264.04 & 6.08 & 132.67 \\
\hline I & 0.2668 & 49.4412 & 4.49 & 171.85 & 17.16 & 268.40 \\
\hline $\mathbf{A}$ & 0.2004 & 49.4516 & 5.87 & 445.43 & 8.47 & 170.39 \\
\hline D & 0.2174 & 49.4491 & 4.32 & 292.04 & 3.23 & 61.02 \\
\hline $\mathbf{L}$ & 0.2836 & 49.4401 & 23.56 & 526.04 & 6.05 & 118.53 \\
\hline $\mathbf{M}$ & 0.3003 & 49.4391 & 8.59 & 221.22 & 5.28 & 99.91 \\
\hline $\mathbf{K}$ & 0.2836 & 49.4416 & 17.58 & 305.66 & 12.50 & 199.08 \\
\hline & & & $9.50 \pm 8.93$ & $310.81 \pm 129.61$ & $19.74 \pm 24.09$ & $157.06 \pm 66.16$ \\
\hline
\end{tabular}

Table 3. Eigenvalues, total variance and cumulative variance of the three factors of the principal component analysis.

\begin{tabular}{llll}
\hline Factor & I & II & III \\
\hline Eigenvalues & 2.90 & 1.67 & 1.26 \\
Total variance (\%) & 41.44 & 23.82 & 17.96 \\
Total variance (cumulative \%) & 41.44 & 65.26 & 83.22 \\
\hline
\end{tabular}


949 Title: Dynamics of phytoplankton productivity and exopolysaccharide (EPS and TEP) pools in the 950 Seine Estuary (Normandy, France) over tidal cycles over two contrasting seasons.

951 Authors: Jérôme Morelle, Mathilde Schapira \& Pascal Claquin

952 Journal: Marine Environmental Research

953

Space and time dynamics of the water column along the salinity gradient

955 At three different sites, in two seasons (winter \& summer), and during a tide cycle, vertical salinity 956 (Practical Salinity Scale; Fig. S1) and temperature $\left({ }^{\circ} \mathrm{C}\right.$; Fig. S1) profiles were performed hourly with a SBE 19-plusVD CTD (Seabird) from the sub-surface down to $1 \mathrm{~m}$ above the water-sediment interface 958 (WSI). Water was sampled $1 \mathrm{~m}$ below the surface and $1 \mathrm{~m}$ above the WSI using a 5L-Niskin bottle at 959 hourly intervals to measure nutrients ( $\mu \mathrm{mol} / \mathrm{L}$; Fig. S2), suspended particular matter (g/L; Fig. S3) and 960 biological parameters (chla, TEP, S-EPS). TEP:chla (mgXGeq/mgchla; Fig. S4) and S-EPS:chla 961 (mgGeq/mgchla; Fig S5) were calculated. The principal values and dynamics of the parameters are 962 described in the main text. 

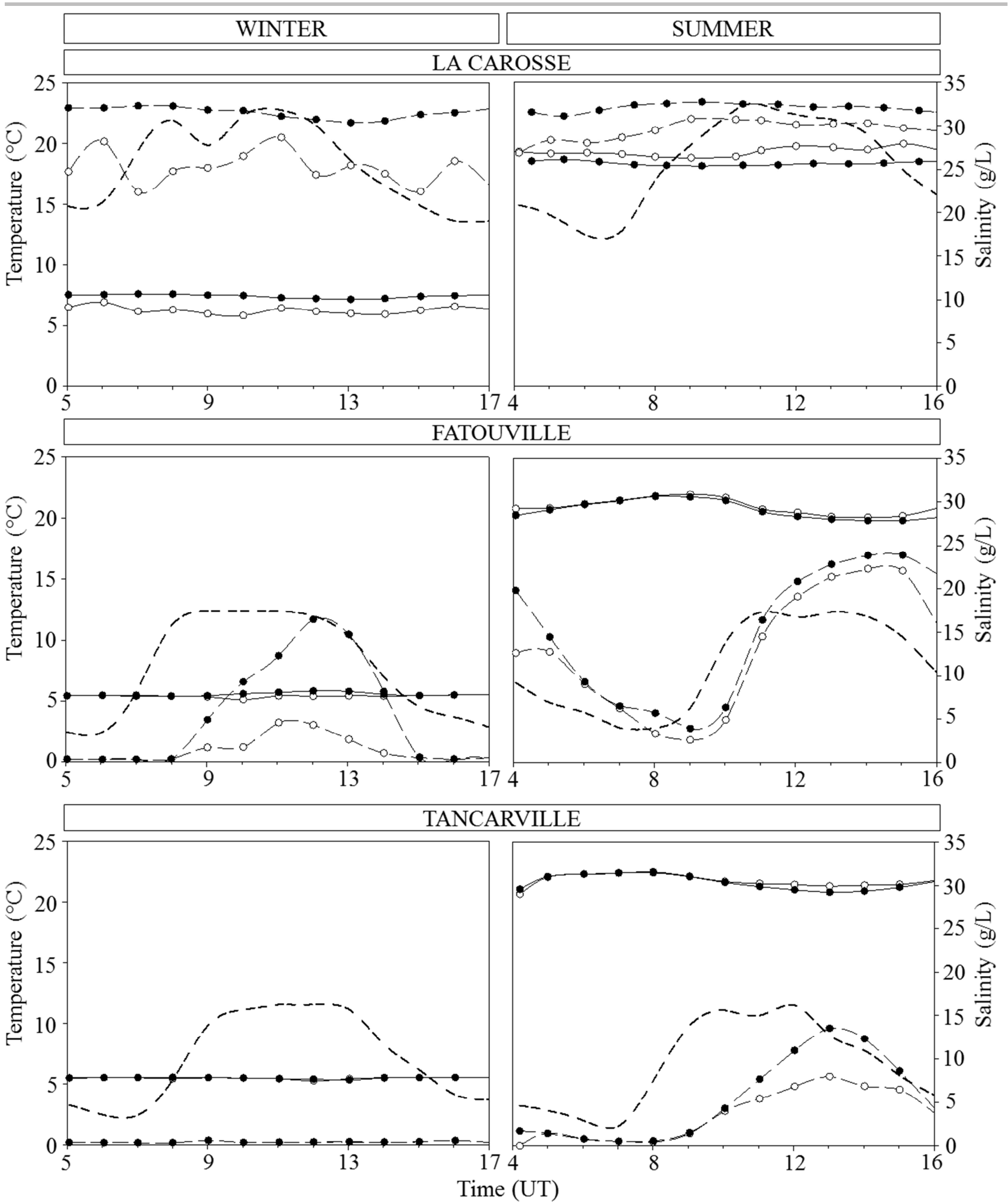

Figure S1. Temperature $\left({ }^{\circ} \mathrm{C}\right.$; triangles) and salinity (circles) over a tidal cycle at the three sampling sites "La Carosse", "Fatouville" \& "Tancarville", in winter (left panel) and in summer (right panel). Sub-surface (1 m) values are represented by empty symbols and values measured close to the bottom (1 m above the WSI) by black symbols. Dotted lines represent the tidal height ( $1 \mathrm{~m}$ above the WSI) in the legend it should be Time (UT) 

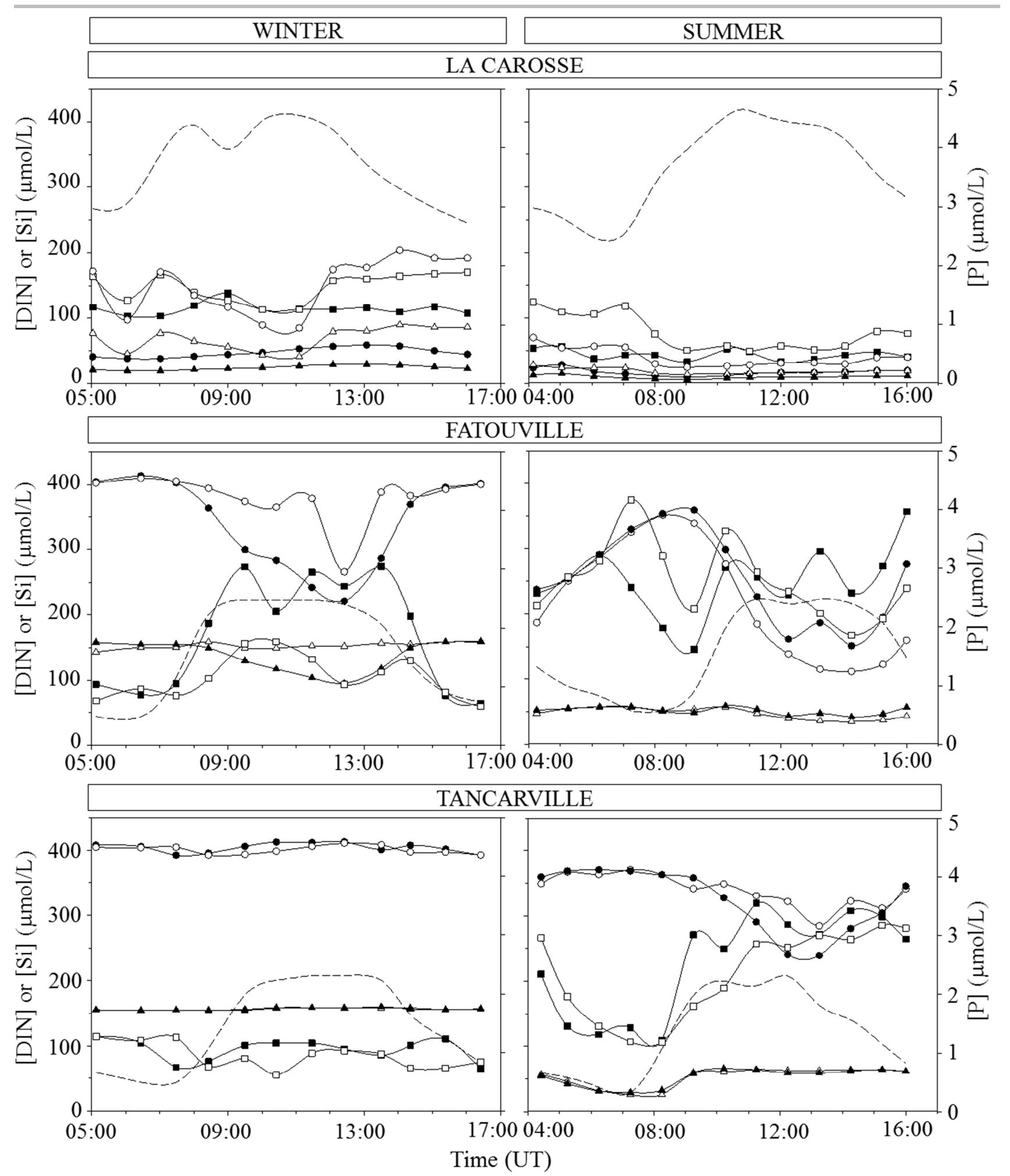

970
Figure S2. Nutrient dynamics $(\mu \mathrm{mol} / \mathrm{L})$ with the dissolved inorganic nitrogen $\left(\mathrm{DIN}=\mathrm{NO}_{3}{ }^{-}+\mathrm{NO}_{2}{ }^{-}+\mathrm{NH}_{4}{ }^{+} ;\right.$circles$)$, phosphate $\left(\mathrm{PO}_{4}{ }^{3-}\right.$; squares) and silicate $\left(\mathrm{Si}(\mathrm{OH})_{4}\right.$; triangles) measured over a tidal cycle at the three sampling sites ("' $\mathrm{La}$ Carosse", "Fatouville" and "Tancarville"), in winter (left panel) and in summer (right panel). Sub-surface values (1 m below the surface) are represented by open symbols and values measured close to the bottom (1 m above the WSI) by black symbols. Dotted lines represent the tidal height (i.e.1 $\mathrm{m}$ above the WSI). 

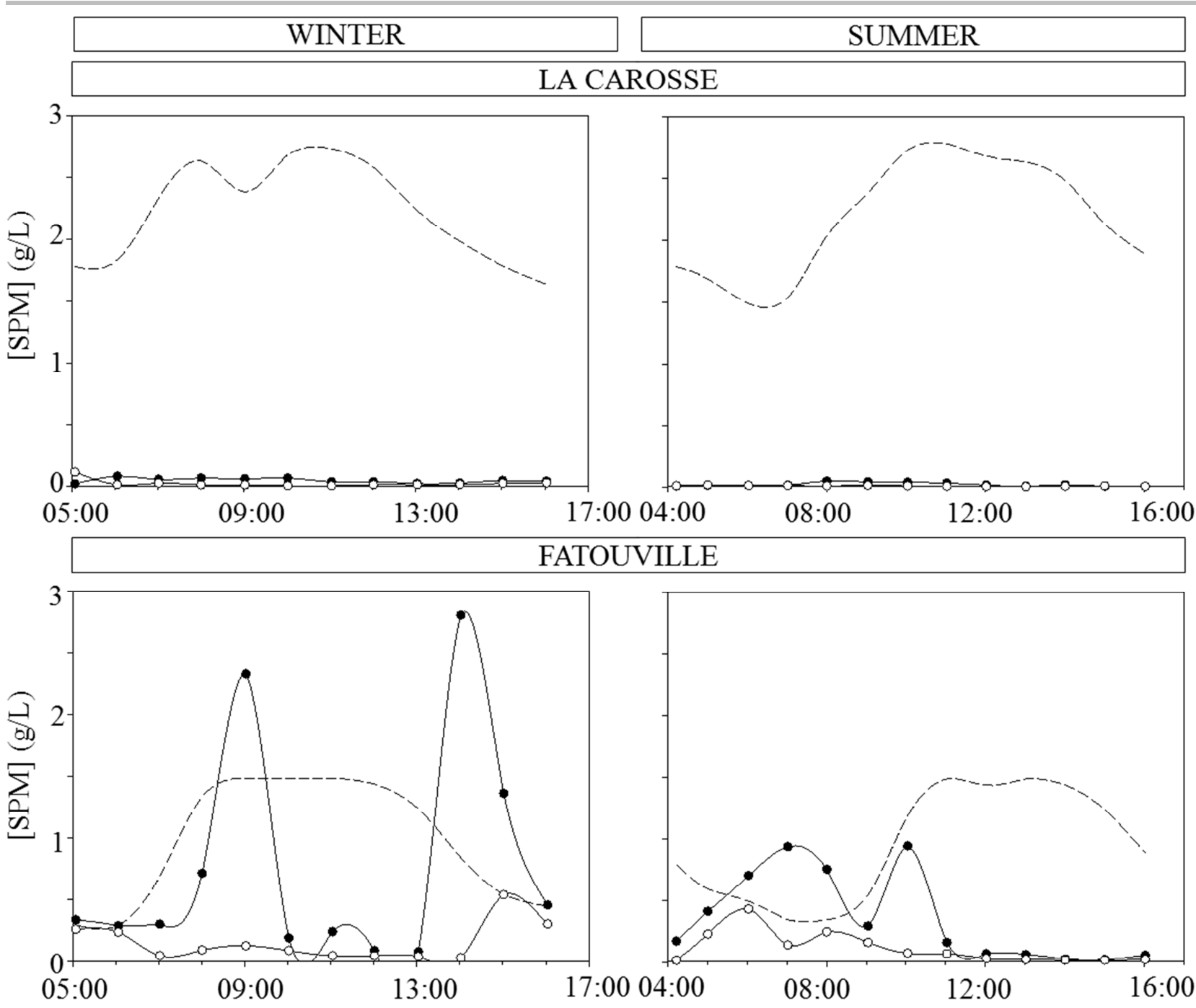

TANCARVILLE

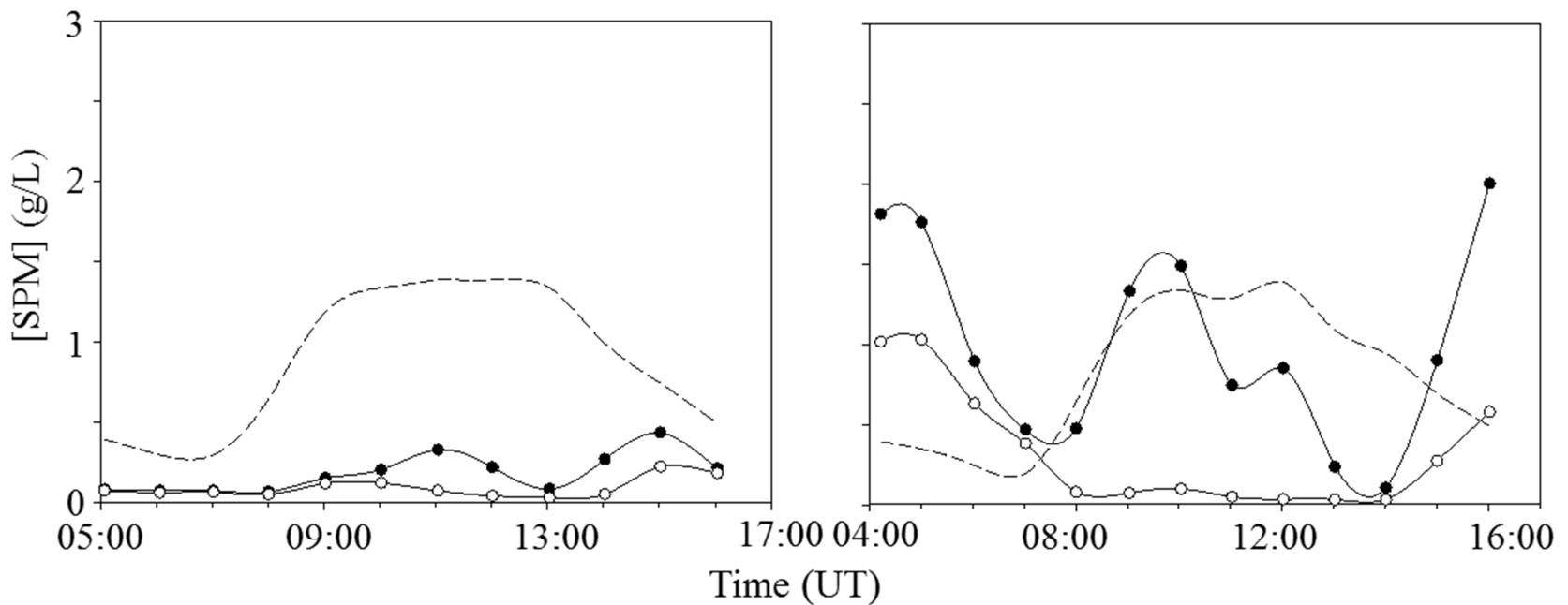

Figure S3. Suspended Particle Matter (SPM: g/L) measured over a tidal cycle at the three sampling sites (La Carosse, Fatouville and Tancarville), in winter (left panel) and in summer (right panel). Values recorded $1 \mathrm{~m}$ below the surface are represented by empty symbols and values measured close to the bottom ( $1 \mathrm{~m}$ above the water sediment interface) by black symbols. The dashed lines represent the tidal height $(\mathrm{m})$. 

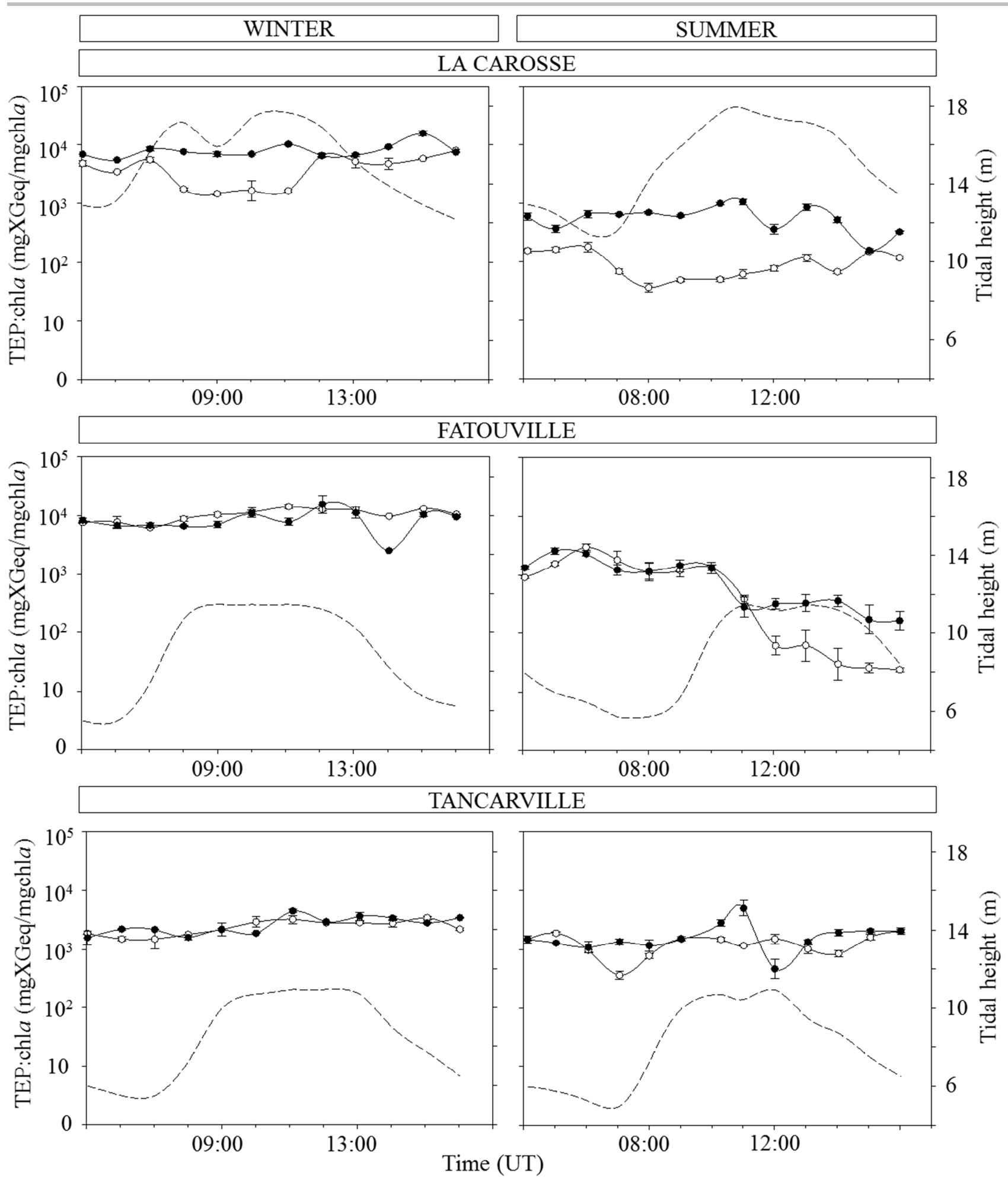

Figure S4. TEP:chla ratios $(\mathrm{mgXGeq} / \mathrm{mg} \operatorname{chl} a$; mean \pm standard error) over a tidal cycle at the three sampling sites shown in logarithmic scale (log10) La Carosse, Fatouville \& Tancarville, in winter (left panel) and in summer (right panel). Values recorded $1 \mathrm{~m}$ below the surface are represented by empty symbols and values measured $1 \mathrm{~m}$ above the WSI by black symbols. The dashed lines represent the tidal height $(\mathrm{m})$. 

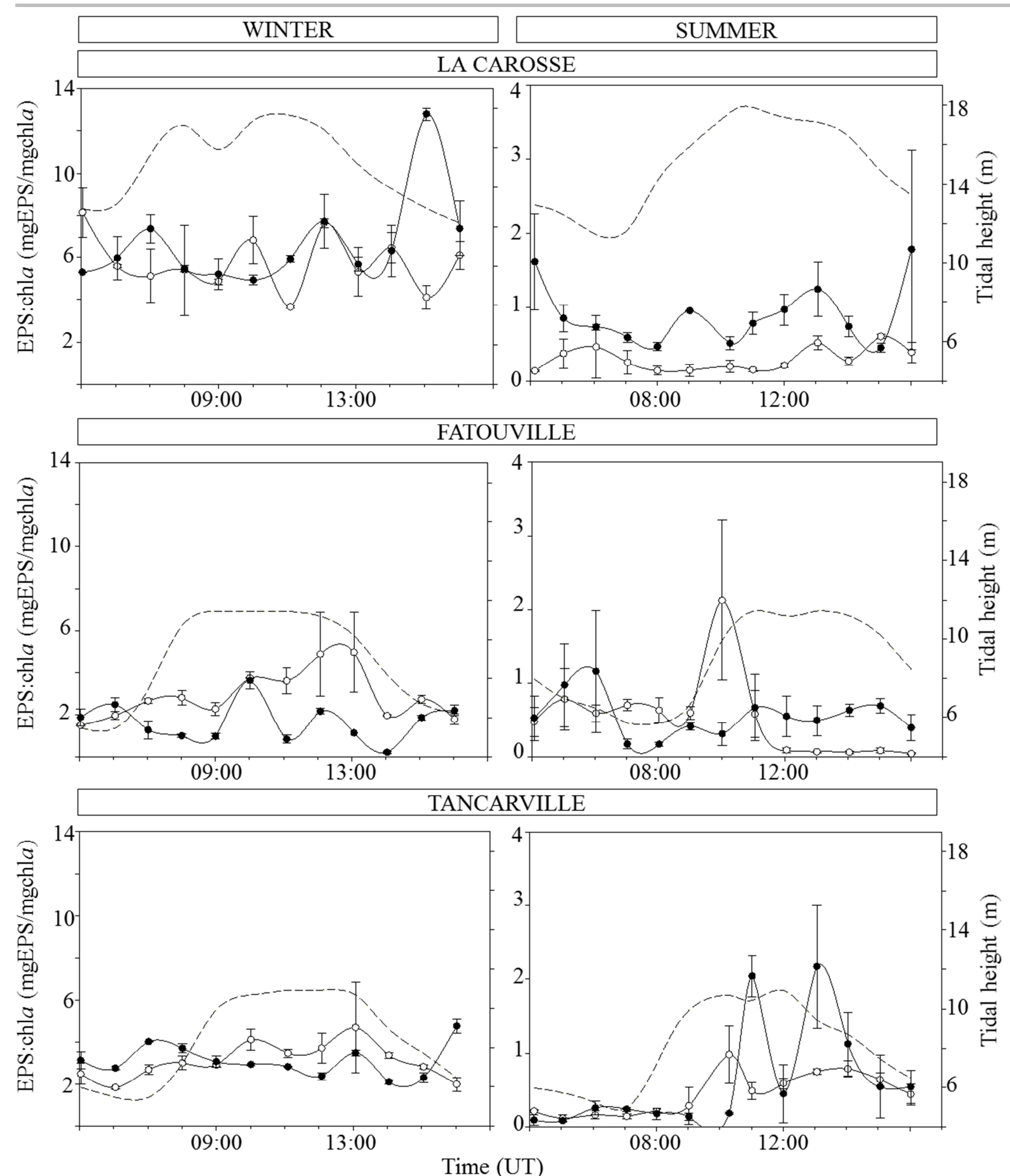

Time (UT)

Figure S5. Variations in S-EPS:chla ratios (mgGeq/mg chla; mean \pm standard error)) over a tidal cycle at the three sampling sites La Carosse, Fatouville \& Tancarville, in winter (left panel) and in summer (right panel). Values recorded 1 $\mathrm{m}$ below the surface are represented by empty symbols and values measured $1 \mathrm{~m}$ above the WSI by black symbols. The dashed lines represent tidal height measured $1 \mathrm{~m}$ above the WSI. 